Prepared in cooperation with the Missouri Department of Natural Resources

\title{
Quality of Surface Water in Missouri, Water Year 2016
}

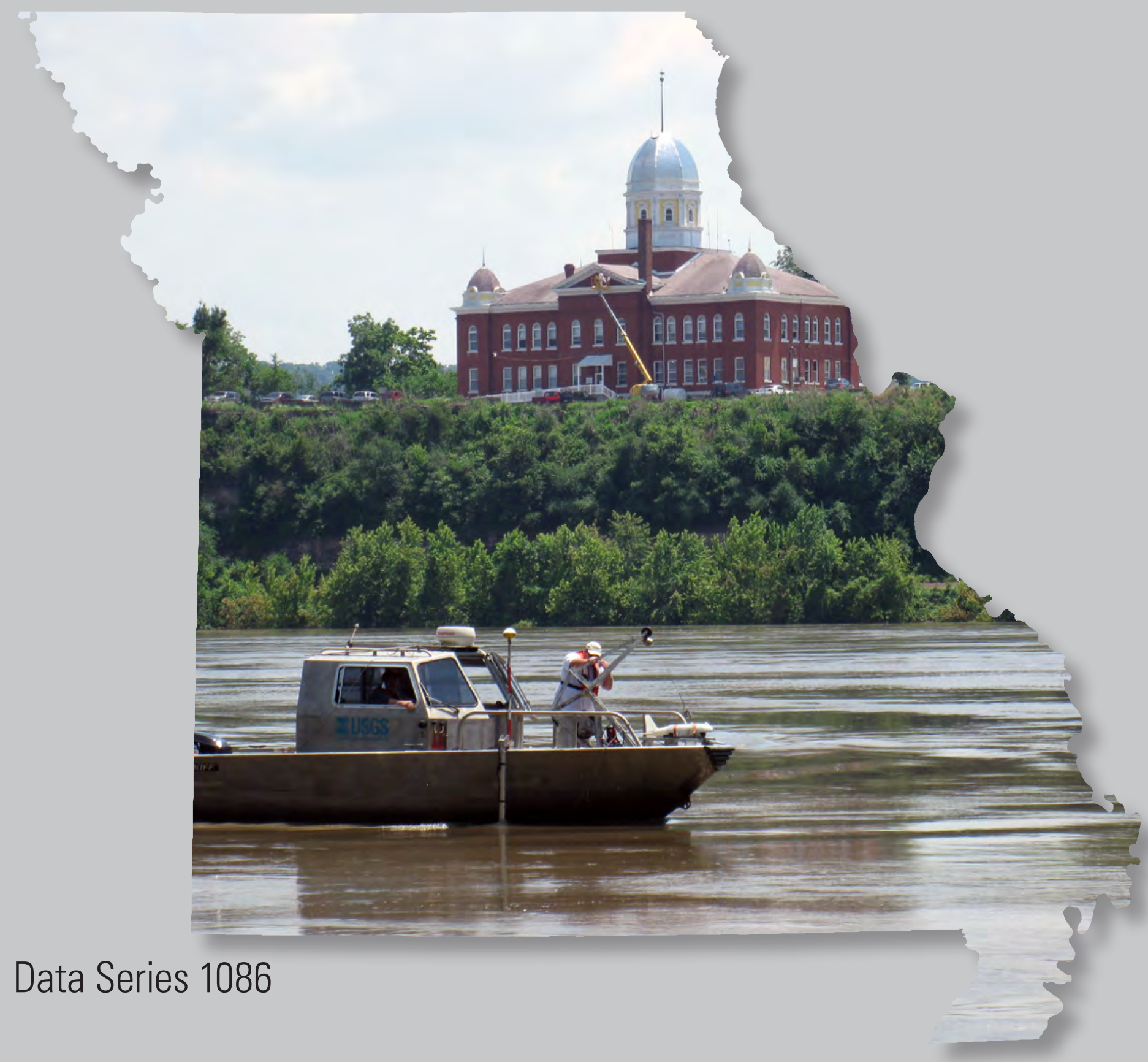

U.S. Department of the Interior

U.S. Geological Survey 
Cover. Hydrologic technicians collecting a surface-water quality sample on the Missouri River at Hermann, Missouri. Photograph by Kelly Brady, hydrologic technician, U.S. Geological Survey. 


\section{Quality of Surface Water in Missouri, Water Year 2016}

By Miya N. Barr and Katherine A. Bartels

Prepared in cooperation with the Missouri Department of Natural Resources

Data Series 1086 


\section{U.S. Department of the Interior \\ RYAN K. ZINKE, Secretary}

\section{U.S. Geological Survey James F. Reilly II, Director}

\section{U.S. Geological Survey, Reston, Virginia: 2018}

For more information on the USGS - the Federal source for science about the Earth, its natural and living resources, natural hazards, and the environment-visit https://www.usgs.gov or call 1-888-ASK-USGS.

For an overview of USGS information products, including maps, imagery, and publications, visit https://store.usgs.gov.

Any use of trade, firm, or product names is for descriptive purposes only and does not imply endorsement by the U.S. Government.

Although this information product, for the most part, is in the public domain, it also may contain copyrighted materials as noted in the text. Permission to reproduce copyrighted items must be secured from the copyright owner.

Suggested citation:

Barr, M.N., and Bartels, K.A., 2018, Quality of surface water in Missouri, water year 2016: U.S. Geological Survey Data Series 1086, 25 p., https://doi.org/10.3133/ds1086.

ISSN 2327-638X (online) 


\section{Contents}

Abstract

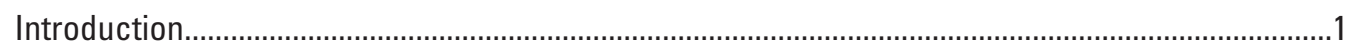

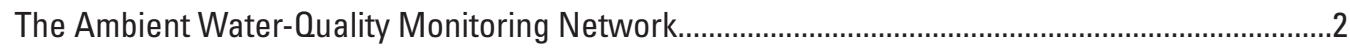

Laboratory Reporting Conventions ........................................................................................

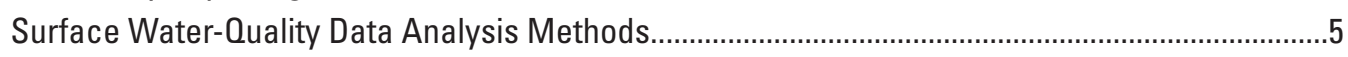

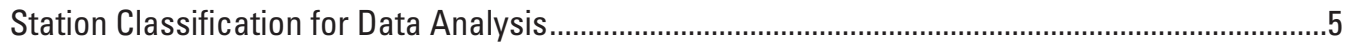

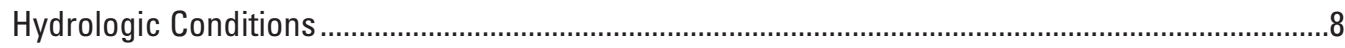

Distribution, Concentration, and Detection Frequency of Select Constituents ...............................12

Distribution of Physical Properties, Suspended-Solids Concentration, Suspended-Sediment Concentration, and Fecal Indicator Bacteria Density.............12

Distribution of Dissolved Nitrate plus Nitrite and Total Phosphorus Concentrations .............12

Distribution of Dissolved and Total Recoverable Lead and Zinc Concentrations...................23

Concentration and Detection Frequency of Select Pesticides from Selected Stations.........23

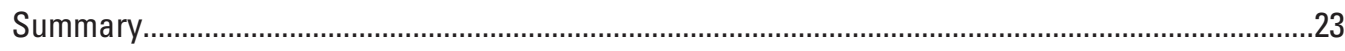

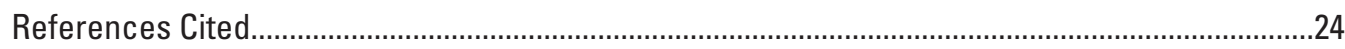

\section{Figures}

1. Map showing location and class of selected stations and physiographic regions

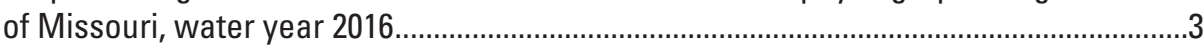

2. Map showing land use and land cover in Missouri.........................................................

3. Map showing location of selected streamflow-gaging stations used for summary of hydrologic conditions within Missouri, water year 2016 .............................................

4. Graphs showing monthly mean streamflow for water year 2016 and long-term mean monthly streamflow at six representative streamflow-gaging stations in Missouri.

5. Boxplots showing distribution of physical properties, suspended-solids concentrations, and suspended-sediment concentrations in samples from 71 stations, water year 2016.

6. Boxplots showing distribution of fecal indicator bacteria density in samples from 71 stations, water year 2016 ..

7. Boxplots showing distribution of dissolved nitrate plus nitrite as nitrogen and total phosphorus concentrations in samples from 71 stations, water year 2016

8. Boxplots showing distribution of dissolved and total recoverable lead and zinc concentrations from 71 stations, water year 2016

9. Graphs showing detection of select pesticides from selected stations, water year 2016 


\section{Tables}

1. U.S. Geological Survey station number, name, contributing drainage area, sampling frequency, and station class and type of 74 selected stations, water year 2016 .

2. Station classes and number of stations in each class and type, water year 2016 ...........8

3. Peak streamflow for water year 2016 and periods of record for selected streamflow-gaging stations

4. Seven-day low flow for water year 2016, period of record 7-day low flow, minimum daily mean streamflow for water year 2016, and period of record minimum daily mean streamflow for selected streamflow-gaging stations in Missouri......

\section{Conversion Factors}

U.S. customary units to the International System of Units

\begin{tabular}{|c|c|c|}
\hline Multiply & By & To obtain \\
\hline \multicolumn{3}{|c|}{ Length } \\
\hline inch (in.) & 2.54 & centimeter $(\mathrm{cm})$ \\
\hline mile (mi) & 1.609 & kilometer (km) \\
\hline \multicolumn{3}{|c|}{ Area } \\
\hline square mile $\left(\mathrm{mi}^{2}\right)$ & 2.590 & square kilometer $\left(\mathrm{km}^{2}\right)$ \\
\hline \multicolumn{3}{|c|}{ Flow rate } \\
\hline cubic foot per second $\left(\mathrm{ft}^{3} / \mathrm{s}\right)$ & 0.02832 & cubic meter per second $\left(\mathrm{m}^{3} / \mathrm{s}\right)$ \\
\hline
\end{tabular}

Temperature in degrees Celsius $\left({ }^{\circ} \mathrm{C}\right)$ may be converted to degrees Fahrenheit $\left({ }^{\circ} \mathrm{F}\right)$ as follows:

$$
{ }^{\circ} \mathrm{F}=\left(1.8 \times{ }^{\circ} \mathrm{C}\right)+32
$$

Horizontal coordinate information is referenced to the North American Datum of 1983 (NAD 83).

Specific conductance is given in microsiemens per centimeter at 25 degrees Celsius $(\mu \mathrm{S} / \mathrm{cm}$ at $\left.25^{\circ} \mathrm{C}\right)$.

Density of bacteria is given in colonies per 100 milliliters $(\mathrm{col} / 100 \mathrm{~mL})$ of water.

Concentrations of chemical constituents in water are given either in milligrams per liter ( $\mathrm{mg} / \mathrm{L}$ ) or micrograms per liter $(\mu \mathrm{g} / \mathrm{L})$.

Water year in U.S. Geological Survey reports is the 12-month period October 1 through September 30 . The water year is designated by the calendar year in which it ends and which includes 9 of the 12 months; thus, the year ending September 30, 2016, is called "water year 2016." 


\section{Abbreviations}

$\begin{array}{ll}\text { AWOMN } & \text { Ambient Water Quality Monitoring Network } \\ \text { LRL } & \text { laboratory reporting level } \\ \text { LT-MDL } & \text { long-term method detection level } \\ \text { MDL } & \text { method detection level } \\ \text { MDNR } & \text { Missouri Department of Natural Resources } \\ \text { MRL } & \text { minimum reporting level } \\ \text { NASQAN } & \text { National Stream Quality Assessment Network } \\ \text { NWIS } & \text { National Water Information System } \\ \text { NWOL } & \text { National Water Quality Laboratory } \\ \text { TMDL } & \text { total maximum daily load } \\ \text { USGS } & \text { U.S. Geological Survey }\end{array}$





\title{
Quality of Surface Water in Missouri, Water Year 2016
}

\author{
By Miya N. Barr and Katherine A. Bartels
}

\section{Abstract}

The U.S. Geological Survey, in cooperation with the Missouri Department of Natural Resources, designed and operates a series of monitoring stations on streams and springs throughout Missouri known as the Ambient Water-Quality Monitoring Network. During water year 2016 (October 1, 2015, through September 30, 2016), data presented in this report were collected at 71 stations: 69 Ambient Water-Quality Monitoring Network stations and 2 U.S. Geological Survey National Stream Quality Assessment Network stations. Among the 71 stations in this report, 4 stations have data presented for additional cooperative efforts with the U.S. Army Corps of Engineers. Dissolved oxygen, specific conductance, water temperature, suspended solids, suspended sediment, Escherichia coli bacteria, fecal coliform bacteria, dissolved nitrate plus nitrite as nitrogen, total phosphorus, dissolved and total recoverable lead and zinc, and select pesticide compound summaries are presented for these 71 stations. The stations primarily have been classified into groups corresponding to the physiography of the State, primary land use, or unique station types. In addition, a summary of hydrologic conditions in the State including peak streamflows, monthly mean streamflows, and 7-day low flows is presented.

\section{Introduction}

The Missouri Department of Natural Resources (MDNR) is responsible for the implementation of the Federal Clean Water Act (33 U.S.C. $\$ 1251$ et seq.) in Missouri. Section 305(b) of the Clean Water Act requires that each State develop a water-quality monitoring program and periodically report the status of its water quality (U.S. Environmental Protection Agency, 1997). Water-quality status is described in terms of the suitability of the water for various uses, such as drinking, fishing, swimming, and supporting aquatic life; these uses formally were defined as "designated uses" in State and Federal regulations. Section 303(d) of the Clean Water Act requires certain waters to be identified and total maximum daily loads (TMDLs) to be determined for waters that do not meet applicable water-quality standards for their designated uses (U.S. Environmental Protection Agency, 2018). TMDLs establish the maximum amount of an impairing substance that a waterbody can assimilate and still meet the water-quality standards. A TMDL addresses a single pollutant for each waterbody.

Missouri has an area of about 69,000 square miles and an estimated population of 6.09 million people (U.S. Census Bureau, 2016). Within Missouri, 115,772 miles (mi) of classified streams support a variety of uses including wildlife, recreation, agriculture, industry, transportation, and public utilities, but only $24,761 \mathrm{mi}$ (or about 21 percent) were monitored, evaluated, and assessed during 2016 (Missouri Department of Natural Resources, 2014a). Of these assessed stream miles, an estimated 5,307 mi fully support the designated uses, and an estimated 5,549 mi are adversely affected (impaired) by various physical changes or chemical contaminants to the point that criteria for at least one of the designated uses no longer can be met (Missouri Department of Natural Resources, 2014a). The impairment has been documented by data that meet the requirements of the 303(d) listing methodology of Missouri.

The U.S. Geological Survey (USGS), in cooperation with the MDNR, collects surface-water quality data pertaining to water resources in Missouri each water year (October 1 through September 30). These data, stored and maintained in the USGS National Water Information System (NWIS) database (https://doi.org/10.5066/F7P55KJN), are collected as part of the Missouri Ambient Water-Quality Monitoring Network (AWQMN) and constitute a source of reliable, impartial, and timely information for developing an enhanced understanding of the State's water resources. To make this information readily available, these data were published annually in the Water-Data Report series from water years 1964 through 2005 (U.S. Geological Survey, 1964-2005). Published data for the 2006 through 2010 water years can be accessed at https:// wdr.water.usgs.gov/ (U.S. Geological Survey, 2006b-2010). Beginning in water year 2011, discrete water-quality data were no longer published annually but can be accessed in the NWIS database at https://nwis.waterdata.usgs.gov/mo/nwis/qwdata.

In addition to the AWQMN stations, select data collected as part of other cooperative efforts also are included in this report to help summarize water-quality conditions across the State. Water samples also are collected by the USGS at two USGS National Stream Quality Assessment Network (NASQAN; a national water-quality sampling network 
operated by the USGS, see https://cida.usgs.gov/quality/rivers/ home) stations. The USGS, in cooperation with the U.S. Army Corps of Engineers, routinely collects suspended-sediment concentration data and various particle-size distribution data on the Missouri and Mississippi Rivers. These data assist with sediment transport and navigable channel assessments along these larger rivers. Sediment samples are collected at seven USGS streamflow-gaging stations within Missouri, but only the four stations where water-quality data also are collected were used for this report. The suspended-sediment concentration data in this report is provided for comparison to the State's total suspended solids criteria.

The purpose of this report is to summarize surface-water quality data collected by the MDNR-USGS cooperative AWQMN for water year 2016. The annual summary of select constituents provides MDNR with current information to assess the quality of surface water within the State and ensure the objectives of the AWQMN are being met. This report is one in a series of annual summaries (Otero-Benitez and Davis, 2009a, 2009b; Barr, 2010, 2011, 2013, 2014, 2015; Barr and Schneider, 2014; Barr and Heimann, 2016). Data on the physical characteristics and water-quality constituents in samples collected during the 2016 water year are presented in figures and tables for 71 surface-water stations - 69 AWQMN stations and 2 NASQAN stations among which are 4 stations with suspended-sediment data collected in cooperation with the U.S. Army Corps of Engineers. The 71 stations presented were classified into groups corresponding to the physiographic regions of the State (fig. 1), primary land use and land cover (fig. 2), or unique station classes and types (fig. 1). Data used to generate information for this report as well as other data not included are available from the NWIS database (U.S. Geological Survey, 2017).

\section{The Ambient Water-Quality Monitoring Network}

The objectives of the AWQMN are to (1) obtain data on the quality and quantity of surface water within the State; (2) provide a historical database of water-quality information that can be used by the State planning and management agencies to make informed decisions about anthropogenic effects (such as agriculture, mining, and urban) on the State's surface waters; and (3) provide for consistent methodology in data collection, laboratory analysis, and data reporting. Constituent concentration data from the AWQMN have been used to determine statewide water-quality status and long-term trends for a 15-year period (Barr and Davis, 2010) to meet information needs of State agencies involved in water-quality planning and management. The data collected also provide support for the design, implementation, and evaluation of preventive and remediation programs.
The MDNR and the USGS established a fixed-station AWQMN in 1964 with 18 stations, 5 of which are being sampled currently (2016). The number of stations within the AWQMN has varied since its inception because of changes in the State's needs. During water year 2016, the AWQMN program consisted of 72 stations (71 primary stations and 1 alternate station). Alternate sampling stations have been established at streamflow-gaging stations near some primary AWQMN stations, and one such station, Drywood Creek near Deerfield, Missouri (06917680), was sampled in October 2015 and September 2016 because of dry conditions at East Drywood Creek at Prairie State Park, Missouri (06917630). Sampling frequency at each station is determined by several factors, including drainage basin size, potential effects from anthropogenic activities (such as agriculture, mining, and urban), history of chemical change, need for annual data, and cost. Each of the streams in the AWQMN is classified for one or more designated uses. For specific information on the designated uses applicable to the streams sampled in the AWQMN, refer to Missouri Department of Natural Resources (2014a; 2014b).

The unique eight-digit number used by the USGS to identify each surface-water station is assigned when a station is first established. The complete eight-digit number for each station includes a two-digit prefix that designates the primary river system (05 is the Upper Mississippi River, 06 is the Missouri River, and 07 is the Lower Mississippi River) plus a six-digit downstream-order number; for example, the station number 05587455 indicates the station is in the Upper Mississippi River system (05), and the remaining six digits (587455) locate the station in downstream order. In this system, the station numbers increase downstream along the main stem. A station on a tributary that enters between two main stem stations is assigned a station number between them.

Methods used for collecting and processing representative water-quality samples are presented in U.S. Geological Survey (variously dated). Onsite measurements of dissolved oxygen, specific conductance, and water temperature were collected at each station according to procedures described in Wilde (variously dated). Samples were collected, analyzed for fecal indicator bacteria (Escherichia coli and fecal coliform), and processed using the membrane filtration procedure described in Myers and others (2014). Methods used by the USGS for collecting and processing representative samples for nutrients, primary chemical constituents, trace elements, suspended solids, suspended sediment, and pesticide analyses are presented in detail in U.S. Geological Survey (2006a), Guy (1969), and Wilde and others (2004). All chemical analyses were done by the USGS National Water Quality Laboratory (NWQL) in Lakewood, Colorado, according to procedures described in Garbarino and others (2006), Fishman (1993), Patton and Kryskalla (2011), Patton and Truitt (1992), Sandstrom and others (2001 and 2015), and Zaugg and others (1995). Suspended-sediment concentrations were computed according to procedures described in Guy (1969). 


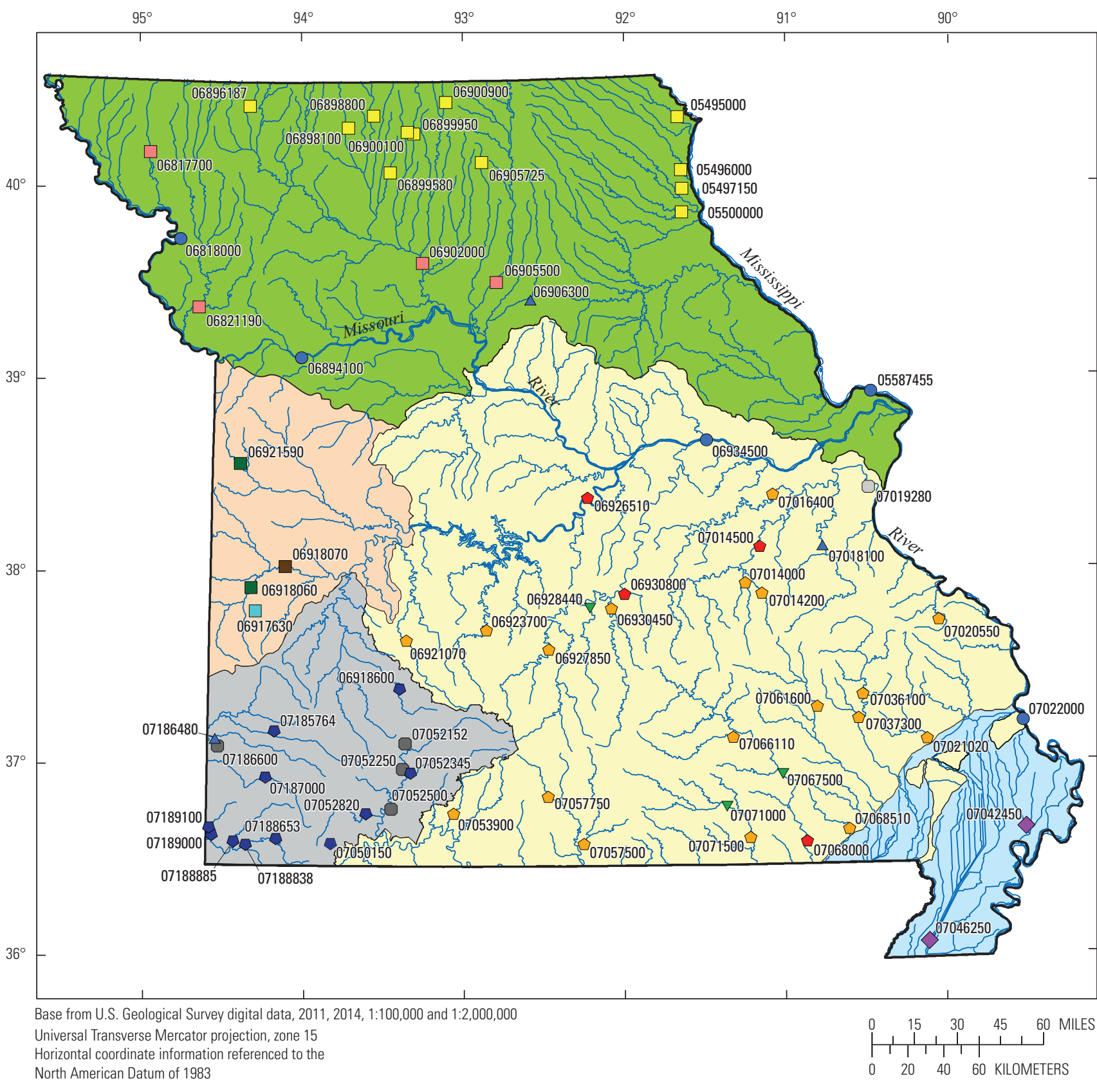

\section{EXPLANATION}

Physiographic regions of Missouri-Modified from Fenneman (1938)

Central Lowland Province—Dissected Till Plains

Central Lowland Province-Osage Plains

Coastal Plain Province-Mississippi Alluvial Plain

Ozark Plateaus Province-Salem Plateau

Ozark Plateaus Province-Springfield Plateau

Ambient Water-Quality Monitoring Network (AWOMN) class and type (table 2) and station number (05500000)

- Big River (BRMIG, BRMIT, BRMOSJ, BRMOS,

$$
\text { and } \mathrm{BRMOH)}
$$

Mississippi Alluvial Plain (MIALPL)

Ozark Plateaus - Salem Plateau forest and

$$
\text { agriculture (OZPLSA fo/ag) }
$$

Ozark Plateaus - Salem Plateau watershed indicator forest and agriculture (OZPLSA wi fo/ag)

- Ozark Plateaus - Springfield Plateau agriculture and forest (OZPLSP ag/fo)

$\square \quad$ Dissected Till Plains agriculture (DTPL ag)

$\square \quad$ Dissected Till Plains watershed indicator, agriculture (DTPL wi ag)

- Osage Plains agriculture (OSPL ag)

- Osage Plains watershed indicator, agriculture (OSPL wi ag)

$\square \quad$ Osage Plains prairie (OSPL pr)

$\nabla \quad$ Springs (SPRING

$\triangle \quad$ Mining (MINING

- Urban (URBAN)

Urban watershed indicator (URBAN wi)

Figure 1. Location and class of selected stations and physiographic regions of Missouri, water year 2016. Modified from Barr and Heimann (2016). 


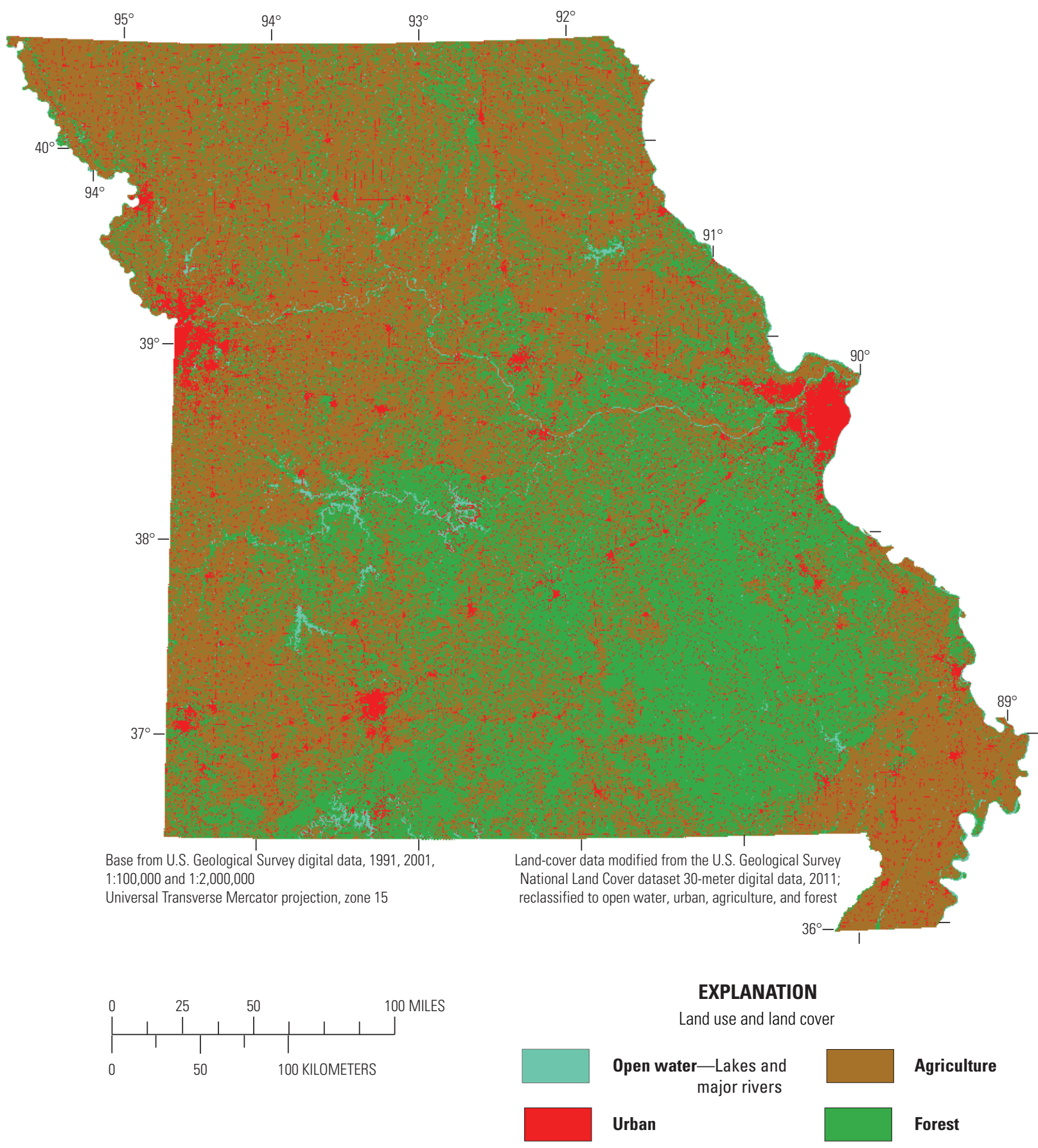

Figure 2. Land use and land cover in Missouri. Modified from Barr and Heimann (2016). 


\section{Laboratory Reporting Conventions}

The NWQL uses method reporting conventions (Childress and others, 1999) to establish the minimum concentration for which more than one qualitative measurement can be made. These reporting conventions are the minimum reporting level (MRL), the method detection level (MDL), and the laboratory reporting level (LRL). The MRL is defined by the NWQL as the smallest measured concentration of a substance that can be measured reliably using a given analytical method. The MDL is the minimum concentration of a substance that can be measured and reported with 99 percent confidence that the concentration is greater than zero. A longterm method detection level (LT-MDL) is a detection level obtained by determining the standard deviation of 24 or more MDL spiked-sample measurements for an extended period. The LRL is computed as twice the LT-MDL. Pesticide data in this report that are not reported as less than $(<)$ the LRL and are graphically displayed below the LRL are estimated values (Childress and others, 1999) and not considered detections.

\section{Surface Water-Quality Data Analysis Methods}

The distribution of select constituent data was displayed graphically using side-by-side boxplots (box and whiskers distributions; Helsel and Hirsch, 2002). The plots show the center of the data (median, the center line of the boxplot), the variation (interquartile range [25th to 75 th percentiles] or the height of the box), the skewness (quartile skew, which is the relative size of the box halves), the spread (upper and lower adjacent values are the vertical lines or whiskers), and the presence or absence of unusual values or outliers. If the median equals the 25th and 75 th percentiles, the boxplot is represented by a single horizontal line. Boxplots with censored data (suspended solids, dissolved nitrate plus nitrite as nitrogen, total phosphorus, and dissolved and total recoverable lead and zinc) were modified by making the lower limit of the box equal to the MRL or LT-MDL as appropriate. For pesticide concentration distributions, censored concentrations (reported as less than the LRL) were included in each distribution as a concentration value equal to the LRL. For some samples, pesticide concentrations are reported as estimated values (Childress and others, 1999), which are included in the distribution as a concentration that is plotted below the LRL and above the LT-MDL. All data used to generate the boxplots can be obtained from the NWIS database (U.S. Geological Survey, 2017). These data can be compiled by the public from NWIS using search criteria such as USGS station identifiers (table 1) and the desired date range.

\section{Station Classification for Data Analysis}

The stations primarily were classified in groups corresponding to the physiography of the State (fig. 1), primary land use and coverage (fig. 2), or unique station classes and types (fig. 1). The physiography-based groups include the Dissected Till Plains (DTPL) in the north, the Osage Plains (OSPL) in the west-central, the Mississippi Alluvial Plain (MIALPL) in the southeast, and the Ozark Plateaus in the middle and southwest. The Ozark Plateaus (Fenneman, 1938) were further subdivided into two distinct groups based on physiographic location - the Salem Plateau (OZPLSA) and the Springfield Plateau (OZPLSP) (fig. 1). Primary land use and cover considered for station classification included agriculture, forest, urban, and mining, but mining is not shown at the scale of the map (fig. 2). Station classes specifically designated by land-use groups include mining (MINING) and urban (URBAN) stations, whereas station classes designated with unique station types refer to springs (SPRING) and the stations on the Mississippi River (BRMIG and BRMIT) and the Missouri River (BRMOSJ, BRMOS, and BRMOH), also referred to in this report as the "Big River stations" (fig. 1).

Some additional variability caused by differences in drainage area and land use was observed within physiographic regions; therefore, contributing drainage area (table 1) and land-use indicators were used to develop a complete set of classes. The land-use indicator provides a subclassification for stations in similar regions with different land uses (fig. 1; table 2). The land-use indicators include watershed indicator stations (wi), which are the most downstream stations in a large watershed and are defined for the purposes of this report as having a drainage area greater than 1,000 square miles, and the secondary land-use and coverage indicator stations, forest (fo), agriculture (ag), and prairie (pr). Unlike data from secondary land-use and coverage indicator stations, observations and analyses from watershed indicator stations can be interpreted as being representative of the general condition of the watershed rather than affected by a specific land use or coverage. In some instances, agriculture and forest land uses were present; therefore, the convention was to mention them in predominant order. The agriculture and forest ( $\mathrm{ag} / \mathrm{fo}$ ) landuse indicator, for example, implies that the primary land use of the watershed is agriculture, although a substantial part of the land coverage is forest.

Three stations from the AWQMN did not fit in the station classes defined for this report (table 2) and were not included. The three excluded stations were Cuivre River near Troy, Missouri (05514500) and Lamine River near Pilot Grove, Missouri (06907300), both within the Ozark Plateaus Province, and Lake Taneycomo at Branson, Missouri (07053700), a station on a semi-riverine system downstream from a major impoundment. 
Table 1. U.S. Geological Survey station number, name, contributing drainage area, sampling frequency, and station class and type of 74 selected stations, water year 2016.

[Water year 2016 is defined as October 1, 2015, through September 30, 2016. USGS, U.S. Geological Survey; mi², square mile; DTPL, Dissected Till Plains; ag, agriculture; --, not available; BRMIG, Big River-Mississippi River below Grafton, Illinois; wi, watershed indicator; BRMOSJ, Big River-Missouri River at St. Joseph, Missouri; BRMOS, Big River-Missouri River at Sibley, Missouri; MINING, mining; OSPL, Osage Plains; pr, prairie; OZPLSP, Ozark PlateausSpringfield Plateau; fo, forest; OZPLSA, Ozark Plateaus-Salem Plateau--, not applicable; SPRING, spring; BRMOH, Big River-Missouri River at Hermann, Missouri; URBAN, urban; BRMIT, Big River-Mississippi River at Thebes, Illinois; MIALPL, Mississippi Alluvial Plain]

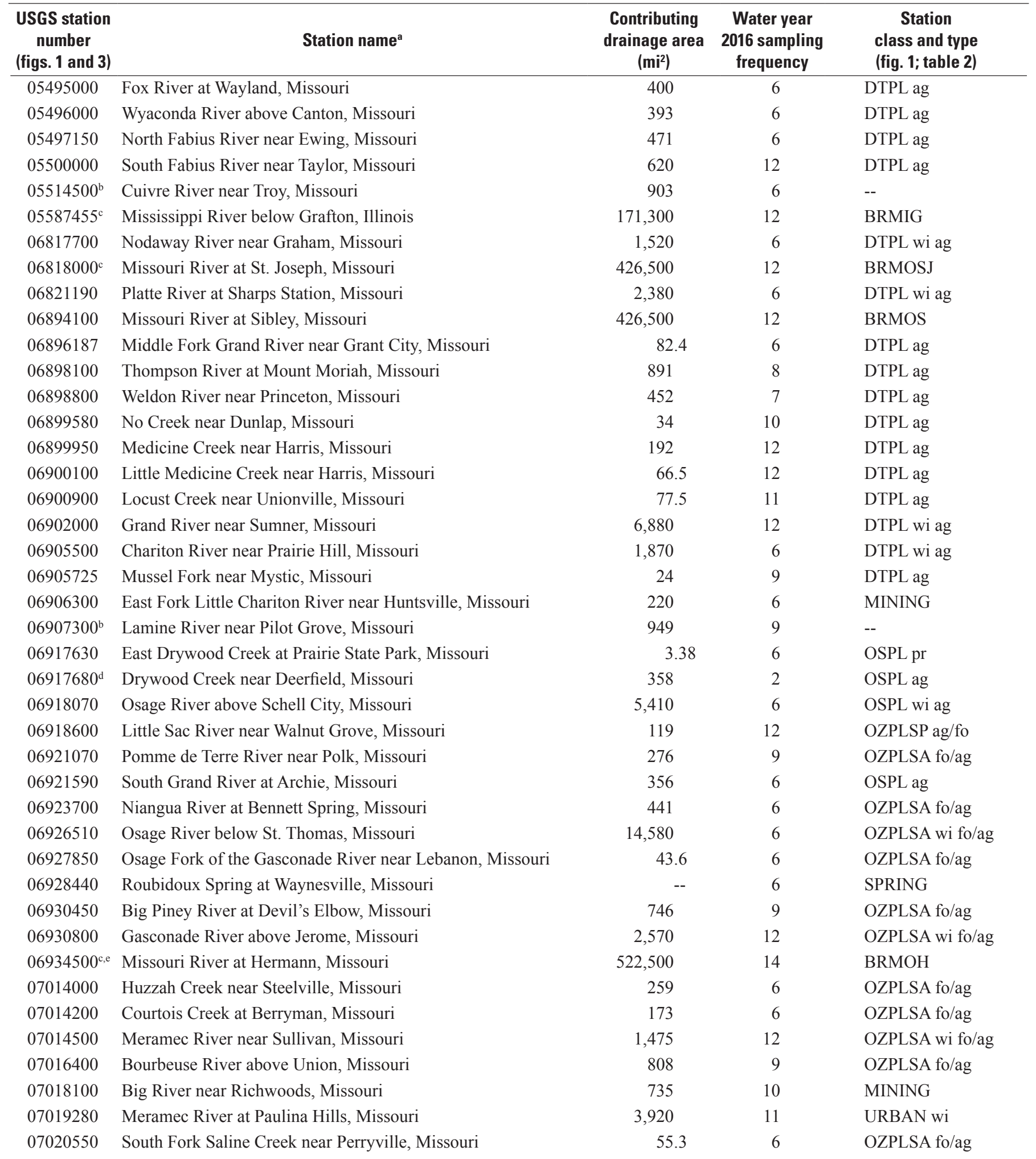


Table 1. U.S. Geological Survey station number, name, contributing drainage area, sampling frequency, and station class and type of 74 selected stations, water year 2016. - Continued

[Water year 2016 is defined as October 1, 2015, through September 30, 2016. USGS, U.S. Geological Survey; mi², square mile; DTPL, Dissected Till Plains; ag, agriculture; --, not available; BRMIG, Big River-Mississippi River below Grafton, Illinois; wi, watershed indicator; BRMOSJ, Big River-Missouri River at St. Joseph, Missouri; BRMOS, Big River-Missouri River at Sibley, Missouri; MINING, mining; OSPL, Osage Plains; pr, prairie; OZPLSP, Ozark PlateausSpringfield Plateau; fo, forest; OZPLSA, Ozark Plateaus-Salem Plateau--, not applicable; SPRING, spring; BRMOH, Big River-Missouri River at Hermann, Missouri; URBAN, urban; BRMIT, Big River-Mississippi River at Thebes, Illinois; MIALPL, Mississippi Alluvial Plain]

\begin{tabular}{|c|c|c|c|c|}
\hline $\begin{array}{c}\text { USGS station } \\
\text { number } \\
\text { (figs. } 1 \text { and } 3 \text { ) }\end{array}$ & Station name ${ }^{a}$ & $\begin{array}{c}\text { Contributing } \\
\text { drainage area } \\
\left(\mathrm{mi}^{2}\right)\end{array}$ & $\begin{array}{l}\text { Water year } \\
2016 \text { sampling } \\
\text { frequency }\end{array}$ & $\begin{array}{c}\text { Station } \\
\text { class and type } \\
\text { (fig. 1; table 2) }\end{array}$ \\
\hline 07021020 & Castor River at Greenbriar, Missouri & 423 & 6 & OZPLSA fo/ag \\
\hline $07022000^{\mathrm{c}, \mathrm{e}}$ & Mississippi River at Thebes, Illinois & 713,200 & 14 & BRMIT \\
\hline 07036100 & St. Francis River near Saco, Missouri & 664 & 9 & OZPLSA fo/ag \\
\hline 07037300 & Big Creek at Sam A. Baker State Park, Missouri & 189 & 6 & OZPLSA fo/ag \\
\hline 07046250 & Little River Ditches near Rives, Missouri & 1,620 & 12 & MIALPL \\
\hline 07050150 & Roaring River Spring at Cassville, Missouri & -- & 6 & OZPLSP ag/fo \\
\hline 07052152 & Wilson Creek near Brookline, Missouri & 51 & 12 & URBAN \\
\hline 07052250 & James River near Boaz, Missouri & 462 & 6 & URBAN \\
\hline 07052345 & Finley Creek below Riverdale, Missouri & 261 & 12 & OZPLSP ag/fo \\
\hline 07053900 & Swan Creek near Swan, Missouri & 148 & 6 & OZPLSA fo/ag \\
\hline 07057500 & North Fork River near Tecumseh, Missouri & 561 & 6 & OZPLSA fo/ag \\
\hline 07057750 & Bryant Creek below Evans, Missouri & 214 & 6 & OZPLSA fo/ag \\
\hline 07061600 & Black River below Annapolis, Missouri & 493 & 8 & OZPLSA fo/ag \\
\hline 07066110 & Jacks Fork above Two River, Missouri & 425 & 12 & OZPLSA fo/ag \\
\hline 07067500 & Big Spring near Van Buren, Missouri & -- & 4 & SPRING \\
\hline 07068000 & Current River at Doniphan, Missouri & 2,040 & 12 & OZPLSA wi fo/ag \\
\hline 07068510 & Little Black River below Fairdealing, Missouri & 194 & 6 & OZPLSA fo/ag \\
\hline 07071000 & Greer Spring at Greer, Missouri & -- & 3 & SPRING \\
\hline 07071500 & Eleven Point River near Bardley, Missouri & 793 & 6 & OZPLSA fo/ag \\
\hline 07188885 & Indian Creek near Lanagan, Missouri & 239 & 12 & OZPLSP ag/fo \\
\hline 07189000 & Elk River near Tiff City, Missouri & 872 & 12 & OZPLSP ag/fo \\
\hline 07189100 & Buffalo Creek at Tiff City, Missouri & 60.8 & 12 & OZPLSP ag/fo \\
\hline
\end{tabular}

${ }^{a}$ Station names were obtained from the U.S. Geological Survey National Water Information System database: https://nwis.waterdata.usgs.gov/mo/nwis/qwdata.

${ }^{b}$ Station data are not included in this report because this station does not fit within the classification system used for this report.

cAdditional water temperature and suspended-sediment samples were collected at this station in cooperation with the U.S. Army Corps of Engineers.

dThis station was sampled as an alternate station when East Drywood Creek at Prairie State Park, Missouri (06901870), was dry.

eStations 06934500 and 07022000 are not part of the Ambient Water-Quality Monitoring Network but were used in this report. Stations 06934500 and 07022000 are funded by the U.S. Geological Survey National Stream Quality Assessment Network. 
Quality of Surface Water in Missouri, Water Year 2016

Table 2. Station classes and number of stations in each class and type, water year 2016.

[Classification system is based on physiography of the State, primary and secondary land use and coverage, unique station type, and drainage area, as well as a station's representativeness to the general condition of the watershed. See the "Station Classification for Data Analysis" section of this report for the full explanation of station classes and types]

\begin{tabular}{|c|c|c|}
\hline \multicolumn{2}{|r|}{ Station class and type (fig. 1) } & \multirow{2}{*}{$\begin{array}{c}\text { Number of stations } \\
\text { (table 1) }\end{array}$} \\
\hline Abbreviation & Definition & \\
\hline BRMIG & Big River-Mississippi River below Grafton, llinois & 1 \\
\hline BRMIT & Big River-Mississippi River at Thebes, Illinois & 1 \\
\hline BRMOSJ & Big River-Missouri River at St. Joseph, Missouri & 1 \\
\hline BRMOS & Big River-Missouri River at Sibley, Missouri & 1 \\
\hline BRMOH & Big River-Missouri River at Hermann, Missouri & 1 \\
\hline MIALPL & Mississippi Alluvial Plain & $2^{\mathrm{a}}$ \\
\hline OZPLSA fo/ag & Ozark Plateaus - Salem Plateau forest and agriculture & 18 \\
\hline OZPLSA wi fo/ag & Ozark Plateaus-Salem Plateau watershed indicator, forest and agriculture & 4 \\
\hline OZPLSP ag/fo & Ozark Plateaus - Springfield Plateau agriculture and forest & 11 \\
\hline DTPL ag & Dissected Till Plains agriculture & 12 \\
\hline DTPL wi ag & Dissected Till Plains watershed indicator, agriculture & 4 \\
\hline OSPL ag & Osage Plains agriculture & 2 \\
\hline OSPL wi ag & Osage Plains watershed indicator, agriculture & 1 \\
\hline OSPL pr & Osage Plains prairie & 1 \\
\hline SPRING & Springs & 3 \\
\hline MINING & Mining & 3 \\
\hline URBAN & Urban & 4 \\
\hline URBAN wi & Urban watershed indicator & 1 \\
\hline
\end{tabular}

${ }^{\mathrm{a} O n e}$ station in this class, Little River Ditches near Rives, Missouri (07046250), has a drainage area greater than 1,000 square miles but is not considered a watershed indicator station because the manmade canals and ditches within its drainage area are not connected hydrologically.

\section{Hydrologic Conditions}

Surface-water streamflow varies seasonally in Missouri and tends to reflect precipitation patterns. During water year 2016, the average annual precipitation of the conterminous United States was 3.80 inches (in.) greater than the 20th century average of $31.07 \mathrm{in}$. (National Oceanic and Atmospheric Administration, 2018a). Total precipitation across Missouri during water year 2016 was 51.52 in., which was greater than the 20th century State precipitation average of $40.79 \mathrm{in}$. (National Oceanic and Atmospheric Administration, 2018b).

The selection of streamflow-gaging stations (hereinafter referred to as "streamgages") used to describe the variation in hydrologic conditions was based on their geographical distribution across the State and a period of record of at least 45 years. This summary of statewide hydrologic condition data or the current (2016) water year in comparison to historical conditions is a legacy of information that was previously provided in the annual Water-Data Reports (U.S. Geological Survey, 1964-2005). Stations with streamgages used for the hydrologic summary are identified in figure 3 .

Six streamgages distributed throughout the State were selected to compare water year 2016 monthly mean streamflow to the long-term mean monthly streamflow (fig. 4). Monthly mean streamflow is the arithmetic mean of daily streamflow for a given month. For comparison to water year 2016, a long-term mean was attained from all monthly mean streamflows for the available period of record. Of these six streamgages, three $(05495000,06921590$, and 07052500$)$ are part of the AWQMN and the remaining three streamgages $(06897500,06933500$, and 07067000$)$ only record streamflow and are not part of the AWQMN (table 1; figs. 3 and 4). Monthly mean streamflows for water year 2016 were higher than the long-term mean from November 2015 through January 2016 for all six streamgages (fig. 4). Missouri experienced high precipitation during this period, and many streamgages 


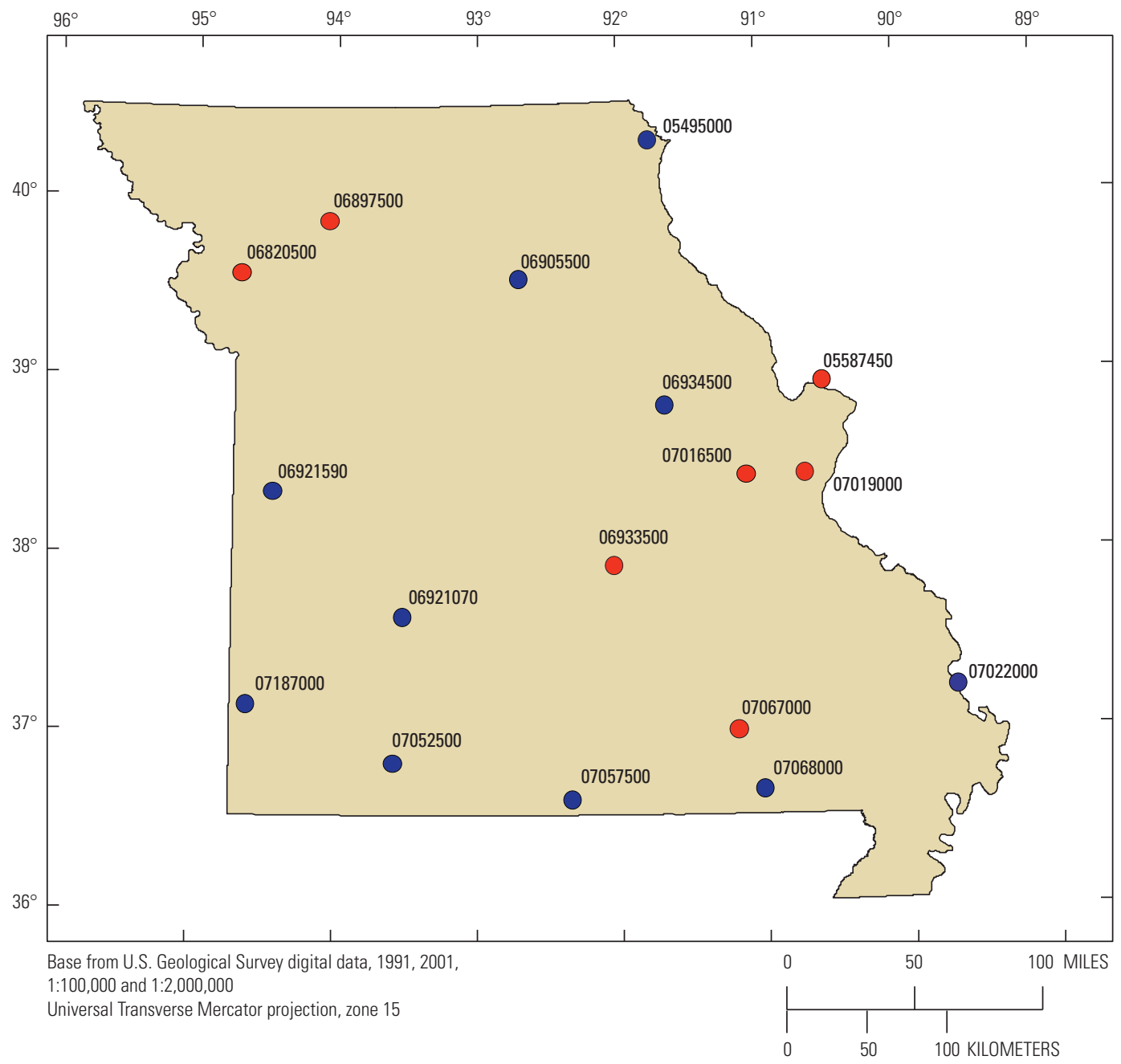

EXPLANATION

06897500 Streamflow-gaging station and station number

05495000 Streamflow-gaging and water-quality station and station number

Figure 3. Location of selected streamflow-gaging stations used for summary of hydrologic conditions within Missouri, water year 2016. Modified from Barr and Heimann (2016).

measured new record streamflows or near record-high streamflows and flooding conditions (table 3). During the remainder of the 2016 water year, the monthly means were similar to the long-term mean streamflows. Two sites (06897500 and 07067000) had larger streamflow in May 2016 than the longterm mean streamflow.

Peak streamflow values for nine streamgages are presented in table 3. During water year 2016, two streamgages (06933500 and 07022000) recorded peak streamflows that exceeded the long-term period of record, creating new peak streamflows. The 7-day low flow for the period of record and water year 2016, and the minimum daily mean flow for the period of record, are presented for selected stations in table 4. The 7-day low flow (the smallest values of mean streamflow computed during any 7-consecutive days during the analysis period) and minimum daily mean flows recorded during water year 2016 were not less than historical records for the stations (table 4). 
05495000 Fox River at Wayland, Missouri ${ }^{1}$

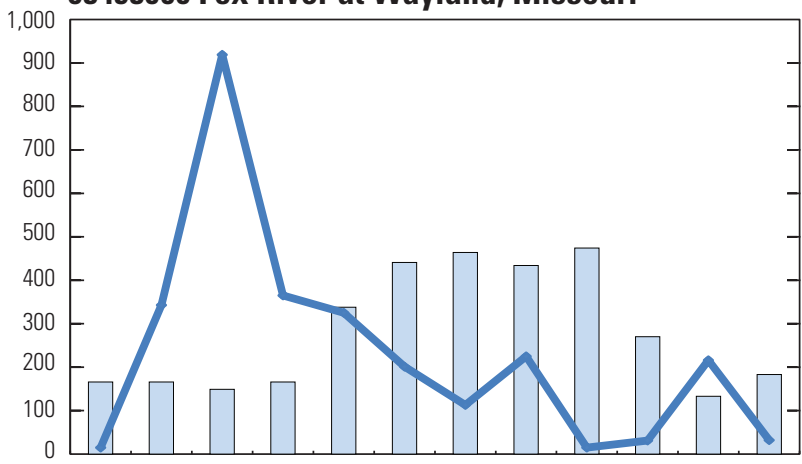

06921590 South Grand River at Archie, Missouri

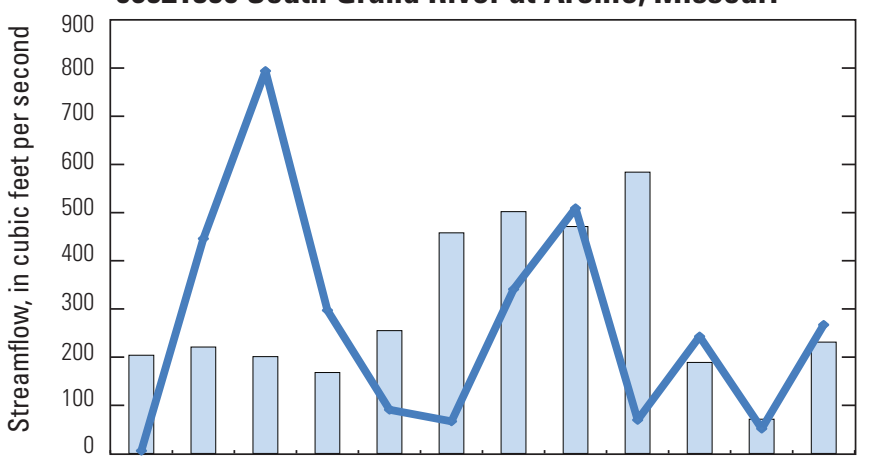

07052500 James River at Galena, Missouri'
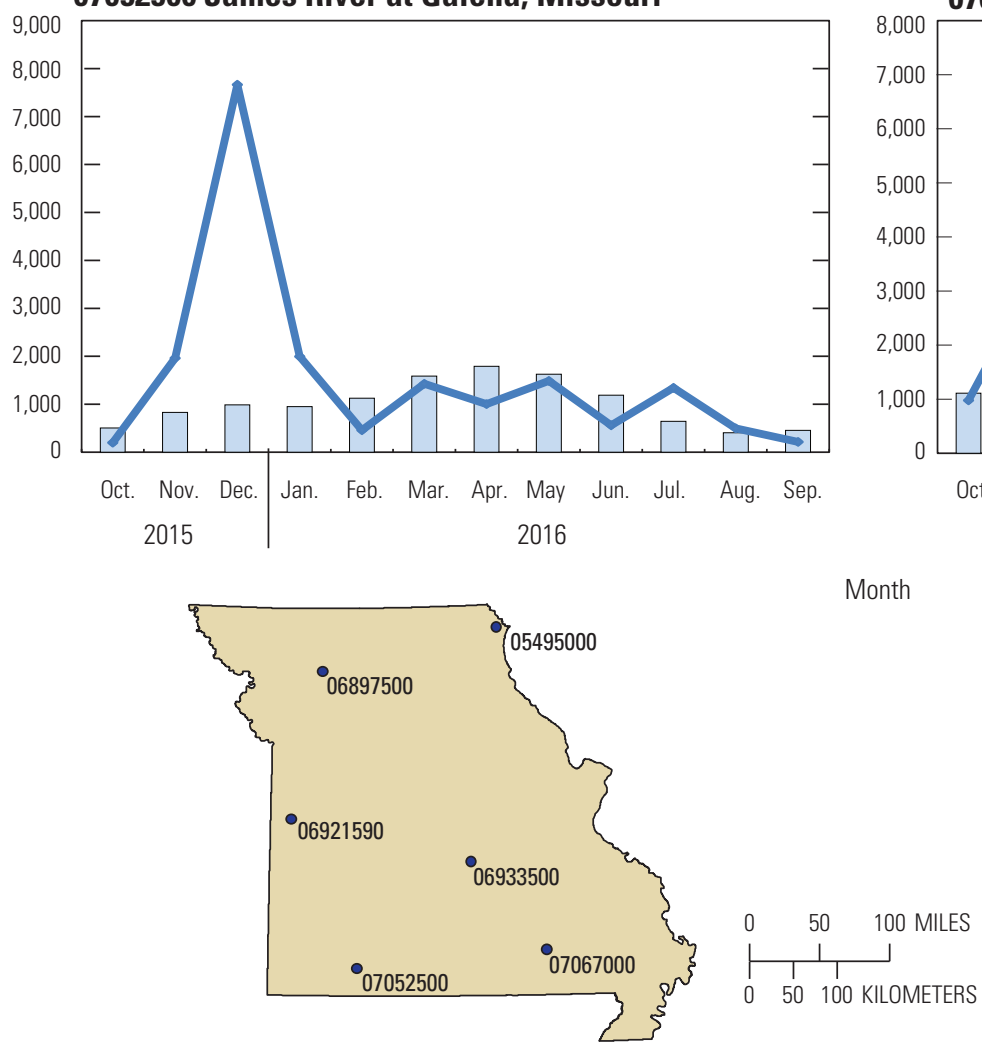

Month
06897500 Grand River near Gallatin, Missouri

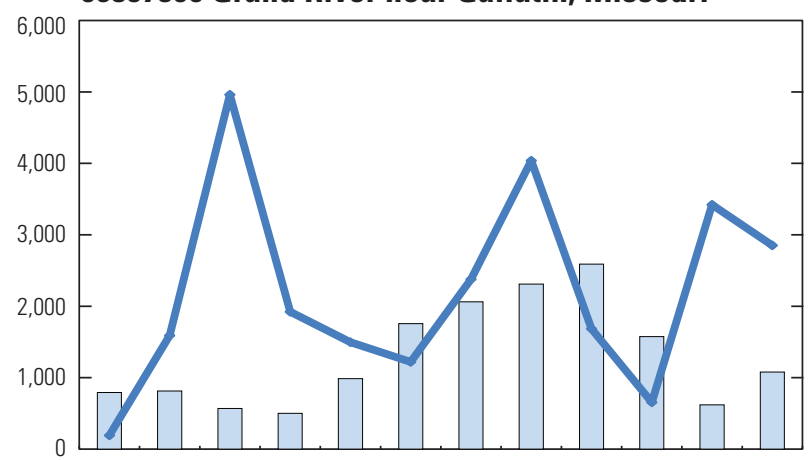

06933500 Gasconade River at Jerome, Missouri
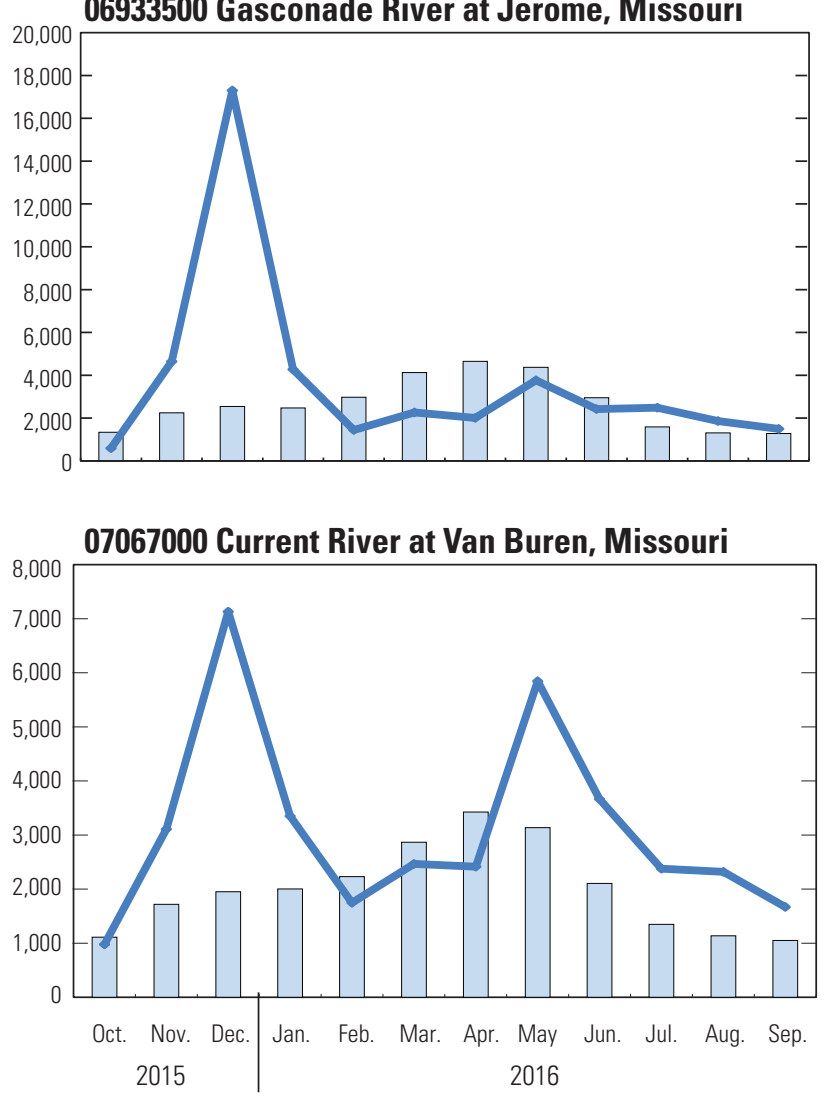

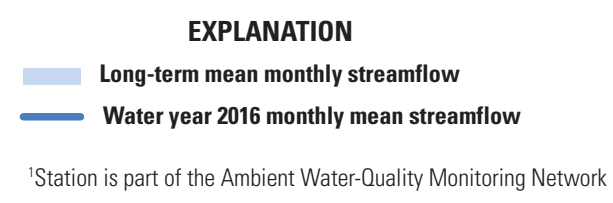

Figure 4. Monthly mean streamflow for water year 2016 and long-term mean monthly streamflow at six representative streamflow-gaging stations in Missouri. 
Table 3. Peak streamflow for water year 2016 and periods of record for selected streamflow-gaging stations.

[Water year 2016 is defined as October 1, 2015, through September 30, 2016. USGS, U.S. Geological Survey; fts, cubic foot per second]

\begin{tabular}{|c|c|c|c|c|c|}
\hline \multirow[b]{2}{*}{$\begin{array}{c}\text { USGS } \\
\text { station number }^{a} \\
\text { (figs. } 1 \text { and } 3 \text { ) }\end{array}$} & \multirow[b]{2}{*}{$\begin{array}{c}\text { Station name }{ }^{\mathrm{b}} \\
\text { (period of record in water years) }\end{array}$} & \multicolumn{2}{|c|}{ Water year 2016} & \multicolumn{2}{|c|}{ Long-term period of record } \\
\hline & & $\begin{array}{c}\text { Peak } \\
\text { streamflow } \\
\left(\mathrm{ft}^{3} / \mathbf{s}\right)\end{array}$ & Date & $\begin{array}{c}\text { Peak } \\
\text { streamflow } \\
\left(\mathrm{ft}^{3} / \mathrm{s}\right)\end{array}$ & Date \\
\hline 05495000 & Fox River at Wayland, Missouri (1922-2016) & 6,230 & Dec. 14,2015 & 26,400 & Apr. 22, 1973 \\
\hline 05587450 & Mississippi River at Grafton, Illinois (1987-2016) & 412,000 & Dec. 30,2015 & 598,000 & Aug. 1, 1993 \\
\hline 06933500 & Gasconade River at Jerome, Missouri (1903-2016) & 140,000 & Dec. 29,2015 & 140,000 & Dec. 29,2015 \\
\hline 06934500 & Missouri River at Hermann, Missouri (1958-2016) & 468,000 & Dec. 29,2015 & 750,000 & July 31, 1993 \\
\hline 07019000 & Meramec River near Eureka, Missouri (1904-2016) & 162,000 & Dec. 30,2015 & 175,000 & Aug. 22,1915 \\
\hline 07022000 & Mississippi River at Thebes, Illinois (1933-2016) & $1,050,000$ & Jan. 2, 2016 & $1,050,000$ & Jan. 2, 2016 \\
\hline
\end{tabular}

aStations 05587450,06933500 , and 07019000 are streamflow-gaging stations only and are not part of the Ambient Water-Quality Monitoring Network.

${ }^{b}$ Station names were obtained from the U.S. Geological Survey National Water Information System database: https:/nwis.waterdata.usgs.gov/mo/nwis/qwdata.

Table 4. Seven-day low flow for water year 2016, period of record 7-day low flow, minimum daily mean streamflow for water year 2016, and period of record minimum daily mean streamflow for selected streamflow-gaging stations in Missouri.

[Water year 2016 defined as October 1, 2015, through September 30, 2016; USGS, U.S. Geological Survey; fts, cubic foot per second]

\begin{tabular}{|c|c|c|c|c|c|c|}
\hline \multirow{2}{*}{$\begin{array}{c}\text { USGS } \\
\text { station number } \\
\text { (figs. } 1 \text { and 3) }\end{array}$} & \multirow{2}{*}{$\begin{array}{c}\text { Station name }{ }^{\mathrm{b}} \\
\text { (period of record in water years) }\end{array}$} & \multicolumn{2}{|c|}{$\begin{array}{l}\text { 7-day low flow } \\
\left(\mathrm{ft}^{3} / \mathrm{s}\right)\end{array}$} & \multicolumn{3}{|c|}{$\begin{array}{l}\text { Minimum daily mean streamflow } \\
\qquad\left(\mathrm{ft}^{3} / \mathrm{s}\right)\end{array}$} \\
\hline & & $\begin{array}{c}\text { Water year } \\
2016\end{array}$ & $\begin{array}{l}\text { Period of } \\
\text { record }\end{array}$ & $\begin{array}{c}\text { Water year } \\
\quad 2016 \\
\end{array}$ & $\begin{array}{l}\text { Period of } \\
\text { record }\end{array}$ & Date \\
\hline 05495000 & Fox River at Wayland, Missouri (1922-2016) & 4.16 & 0 & 3.10 & 0 & Sept. 10,1930 \\
\hline 06820500 & Platte River near Agency, Missouri (1933-2016) & 214 & 0 & 200 & 0 & July 19, 1934 \\
\hline 07016500 & Bourbeuse River near Union, Missouri (1921-2016) & 36.9 & 13 & 36.5 & 12 & Oct. 10,1956 \\
\hline 07067000 & Current River at Van Buren, Missouri (1912-2016) & 946 & 479 & 940 & 476 & Oct. 8, 1956 \\
\hline 07187000 & Shoal Creek above Joplin, Missouri (1942-2016) & 123.6 & 16 & 117.0 & 15 & Sept. 7, 1954 \\
\hline
\end{tabular}

aStations 06820500, 07016500, and 07067000 are streamflow-gaging stations only and are not part of the Ambient Water-Quality Monitoring Network (AWQMN).

${ }^{b}$ Station names were obtained from the U.S. Geological Survey National Water Information System database: https://nwis.waterdata.usgs.gov/mo/nwis/qwdata. 


\section{Distribution, Concentration, and Detection Frequency of Select Constituents}

The analyses presented in this report include the following constituents: dissolved oxygen, specific conductance, water temperature, suspended solids, suspended sediment, Escherichia coli bacteria, fecal coliform bacteria, dissolved nitrate plus nitrite as nitrogen (hereinafter referred to as "nitrate plus nitrite"), total phosphorus, and dissolved and total recoverable lead and zinc. Boxplots of these constituents are presented for the different station classes (figs. 5-8). In addition, pesticide data were analyzed from seven stations from six classes (fig. 9). Three Big River stations and classes (05587455 in class BRMIG; 06934500 in class BRMOH; and 07022000 in class BRMIT) had pesticide analyses completed as part of the NASQAN program, which began using an experimental method for pesticide analyses during water year 2013 (Sandstrom and Wilde, 2014 and Sandstrom and others, 2015). Many constituents available using the experimental method were similar to the constituents available with traditional pesticide sampling methods used for the AWQMN stations (06918070 in class OSPL wi ag; 07042450 and 07046250 in class MIALPL; 07052250 in class URBAN; fig. 1; table 1), but some have different LRLs because of the experimental method (fig. 9). Of the 85 pesticide constituents analyzed for the AWQMN and the 228 pesticide constituents analyzed as part of the NASQAN program during water year 2016, 18 had concentrations that were larger than their LRL in at least one sample, were common to both sampling methods, and are presented in this report: 2-chloro-4-isopropylamino6-amino-s-triazine (more commonly referred to as CIAT, a degradation product of atrazine), acetochlor, alachlor, atrazine, cyanazine, hexazinone, malathion, metalaxyl, metolachlor, metribuzin, pendamethalin, phorate, prometon, prometryn, propyzamide, simazine, tebuthiuron, and terbuthylazine (fig. 9). Missouri water-quality standards are not shown on the graphs because these standards are not applicable to all streams in the AWQMN. For specific information on Missouri water-quality standards, refer to Missouri Department of Natural Resources (2014b).

\section{Distribution of Physical Properties, Suspended- Solids Concentration, Suspended-Sediment Concentration, and Fecal Indicator Bacteria Density}

The physical properties analyzed for this report were dissolved oxygen, specific conductance, and water temperature. The median dissolved oxygen, in percent saturation, ranged from 73 to 104 percent (fig. 5). Samples from OSPL wi ag stations had the smallest median dissolved oxygen percent saturation values, whereas samples from URBAN stations had the largest median dissolved oxygen (fig. 5). Median specific conductance values varied substantially among the station classes (fig. 5), ranging from 110 microsiemens per centimeter at 25 degrees Celsius $\left(\mu \mathrm{S} / \mathrm{cm}\right.$ at $\left.25^{\circ} \mathrm{C}\right)$ at the OSPL pr station to $834 \mu \mathrm{S} / \mathrm{cm}$ at $25{ }^{\circ} \mathrm{C}$ at the BRMOSJ station. Median water temperature ranged from 9.6 to 18.5 degrees Celsius; the smallest median temperature was measured at the URBAN wi station, and the largest was measured at OSPL wi ag station (fig. 5). The interquartile range in water temperature at the SPRING stations was much smaller than for other station classes and types.

Suspended solids and suspended sediment are measures of the solid material suspended in the water column. These two measures are not considered directly comparable because of differences in collection and analytical techniques. Suspended-solids concentrations were determined for all station classes and types except BRMIT and BRMOH. Median suspended-solids concentrations varied considerably among all station classes, ranging from 15 to 164 milligrams per liter (mg/L; fig. 5). Samples collected at the OZPL (SA fo/ ag, SA wi fo/ag, and SP ag/fo), OSPL pr, SPRING, MINING, and URBAN stations had median concentrations at the MRL (15 mg/L). The BRMOS station had the largest median suspended-solids concentrations (164 mg/L). Suspendedsediment concentrations were determined at four Big River stations (fig. 5). The suspended-sediment data used in this report consist of composited cross-sectional concentrations and average cross-sectional concentrations computed from five depth-integrated samples within the cross section (Edwards and Glysson, 1999). Additional suspended-sediment concentrations from individual depth-integrated samples within cross sections are available through the NWIS database (https://nwis.waterdata.usgs.gov/mo/nwis/qwdata). Median suspended-sediment concentrations ranged from $140 \mathrm{mg} / \mathrm{L}$ at BRMIG to $348 \mathrm{mg} / \mathrm{L}$ at BRMOH (fig. 5).

Median Escherichia coli and fecal coliform bacteria densities varied considerably among all station classes and types (fig. 6). Median Escherichia coli bacteria density ranged from 6 to 1,050 colonies per 100 milliliters of water, and fecal coliform bacteria density ranged from 12 to 1,200 colonies per 100 milliliters of water (fig. 6). The smallest median densities were in samples collected at SPRING stations, whereas the largest median densities were in samples collected at the BRMOS station (fig. 6).

\section{Distribution of Dissolved Nitrate plus Nitrite and Total Phosphorus Concentrations}

Samples were collected at all stations for the analysis of nutrients, including dissolved nitrate plus nitrite and total phosphorus. Median dissolved nitrate plus nitrite and total phosphorus concentrations varied considerably among all station classes and types (fig. 7), ranging from 0.04 to $4.14 \mathrm{mg} / \mathrm{L}$ for nitrate plus nitrite and 0.02 to $0.38 \mathrm{mg} / \mathrm{L}$ for total phosphorus. The smallest median dissolved nitrate plus 


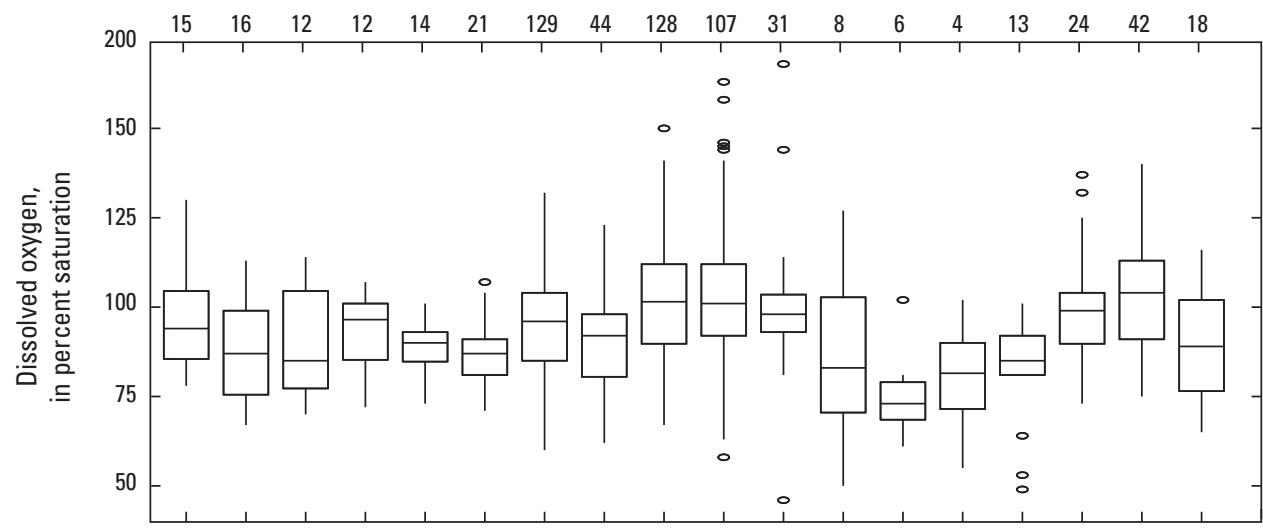

EXPLANATION

Number of samples

Upper outlier

Upper adjacent

75th percentile

Median

25th percentile

Lower adjacent

Lower outlier
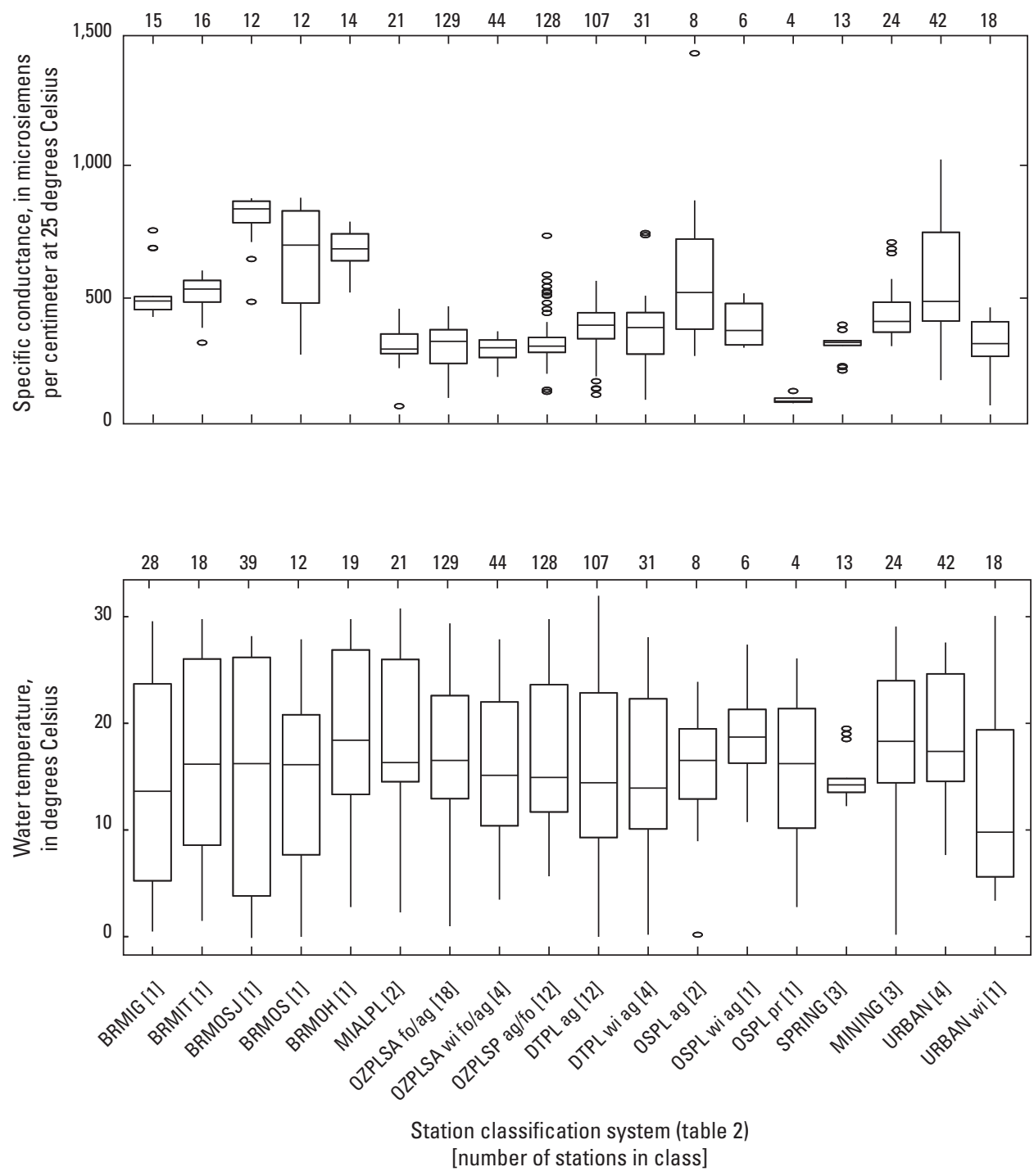

Figure 5. Distribution of physical properties, suspended-solids concentrations, and suspended-sediment concentrations in samples from 71 stations, water year 2016. 

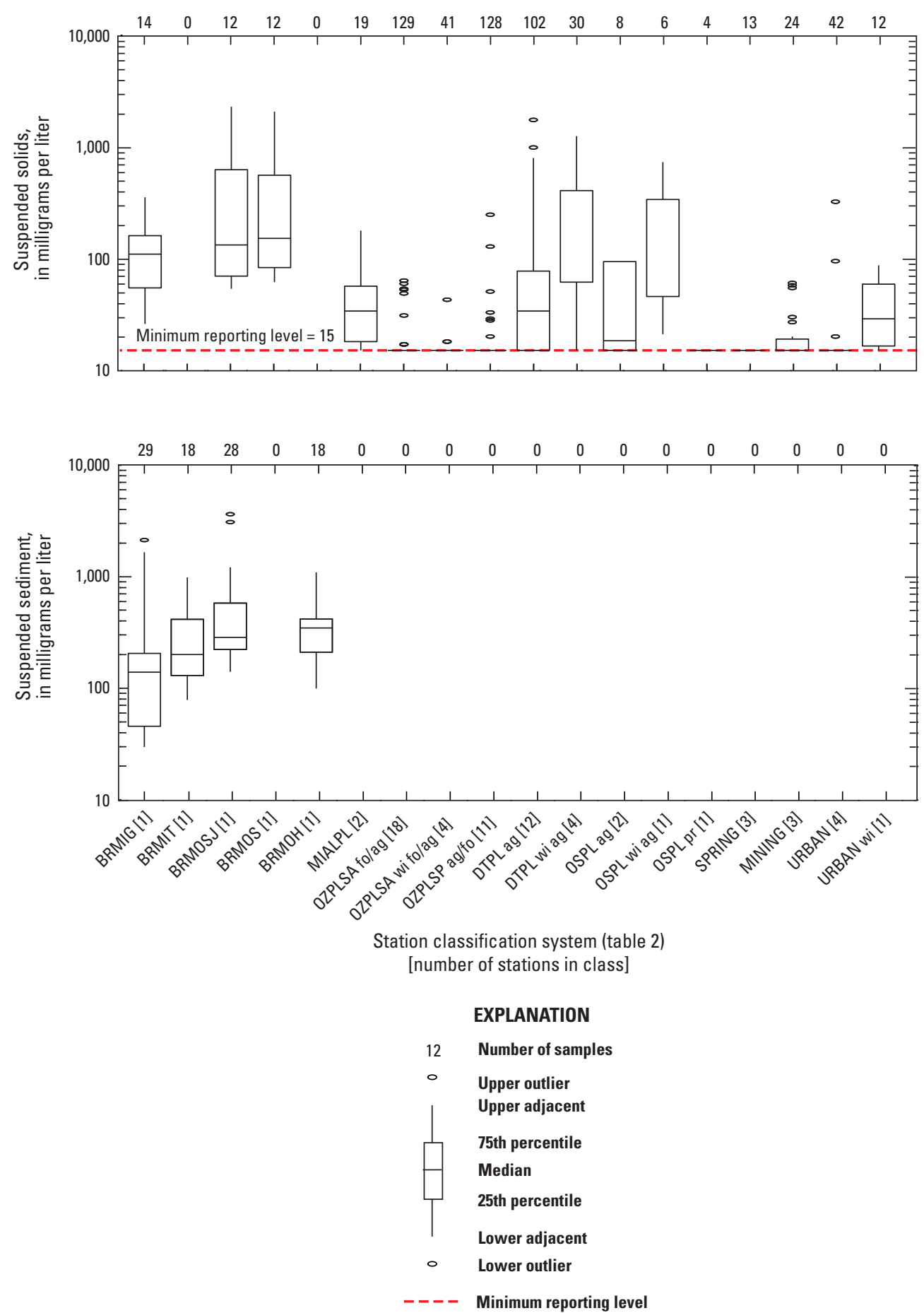

Figure 5. Distribution of physical properties, suspended-solids concentrations, and suspendedsediment concentrations in samples from 71 stations, water year 2016.-Continued 

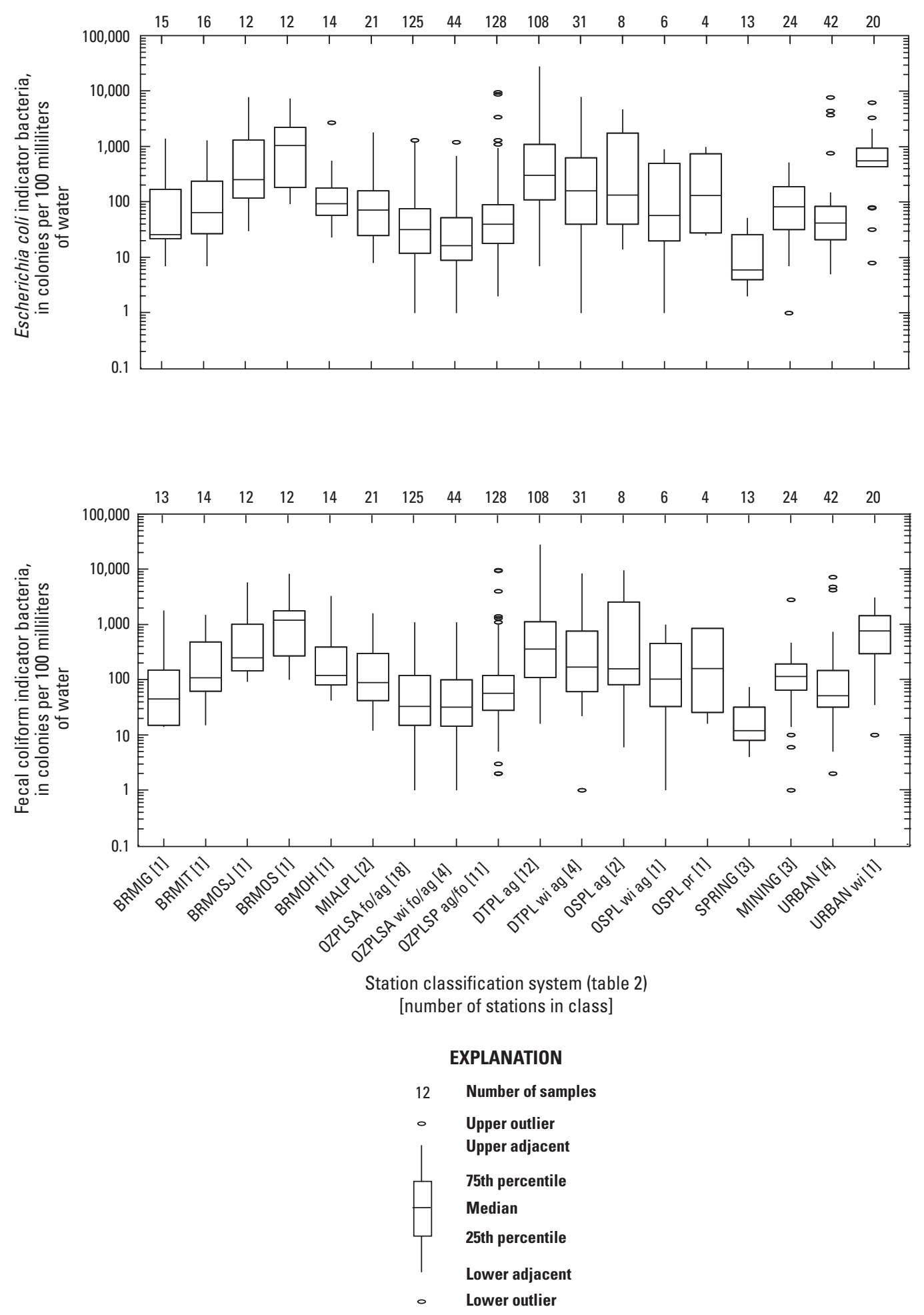

Figure 6. Distribution of fecal indicator bacteria density in samples from 71 stations, water year 2016. 

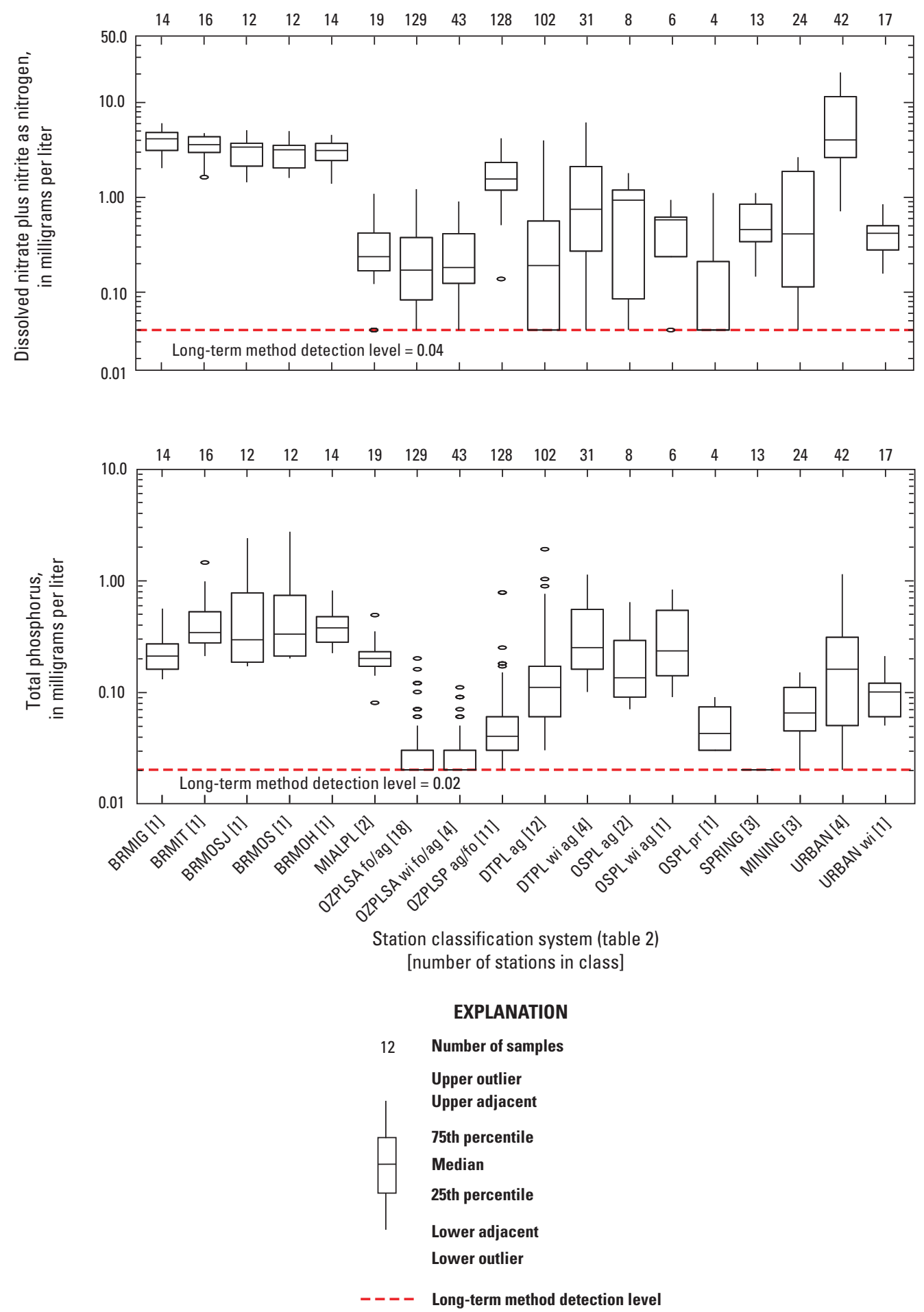

Figure 7. Distribution of dissolved nitrate plus nitrite as nitrogen and total phosphorus concentrations in samples from 71 stations, water year 2016. 

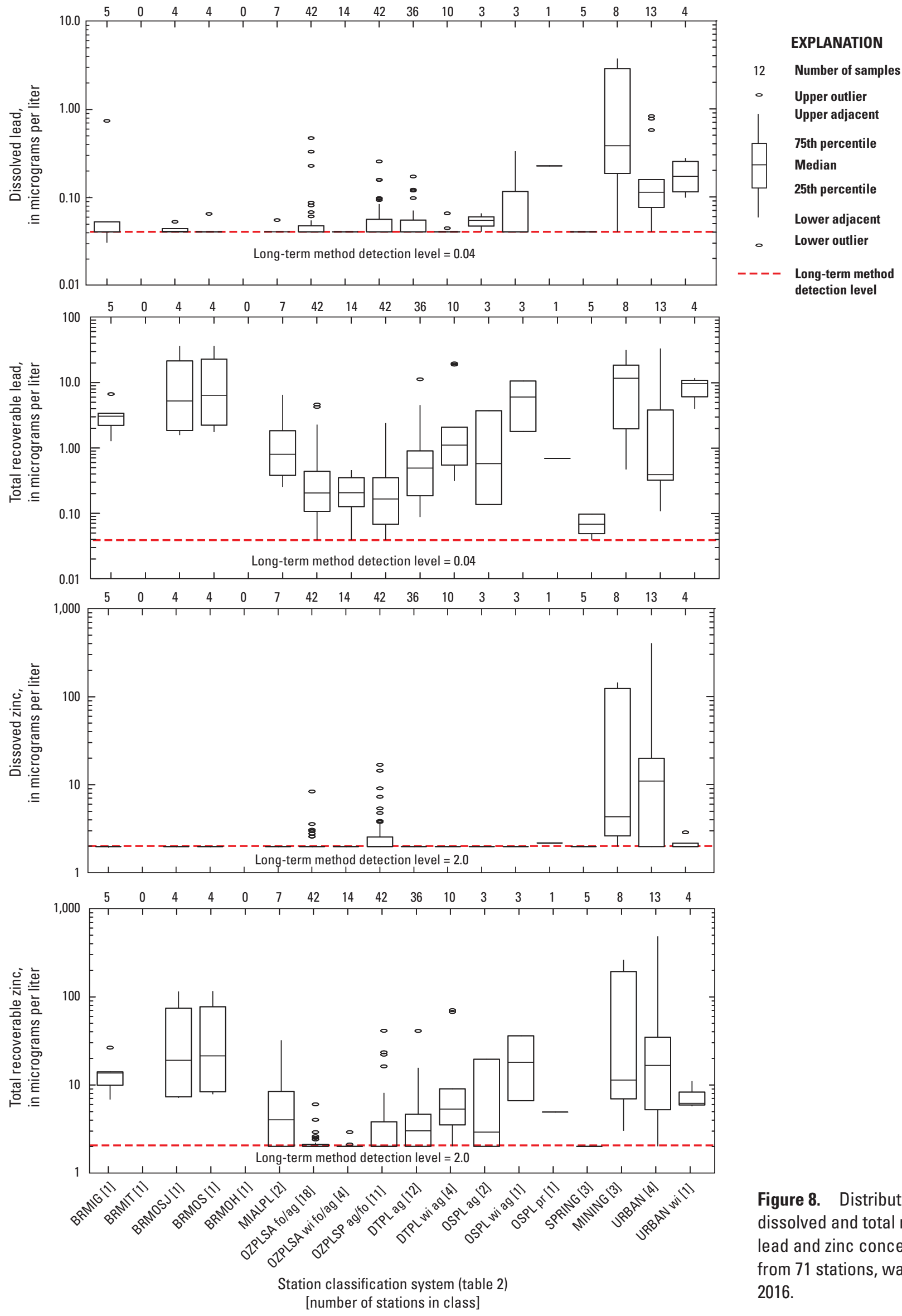

Figure 8. Distribution of dissolved and total recoverable lead and zinc concentrations from 71 stations, water year 2016. 


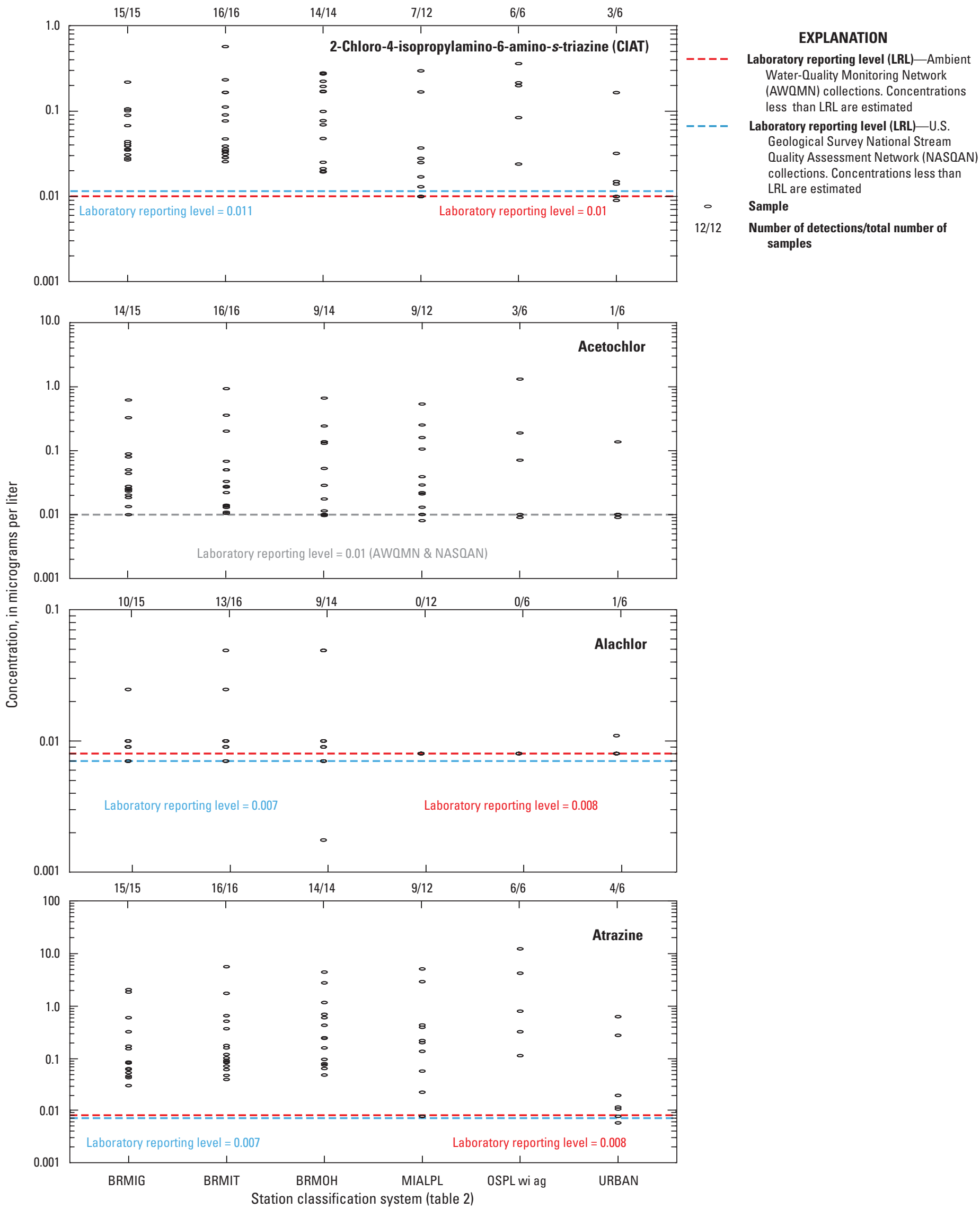

Figure 9. Detection of select pesticides from selected stations, water year 2016. 


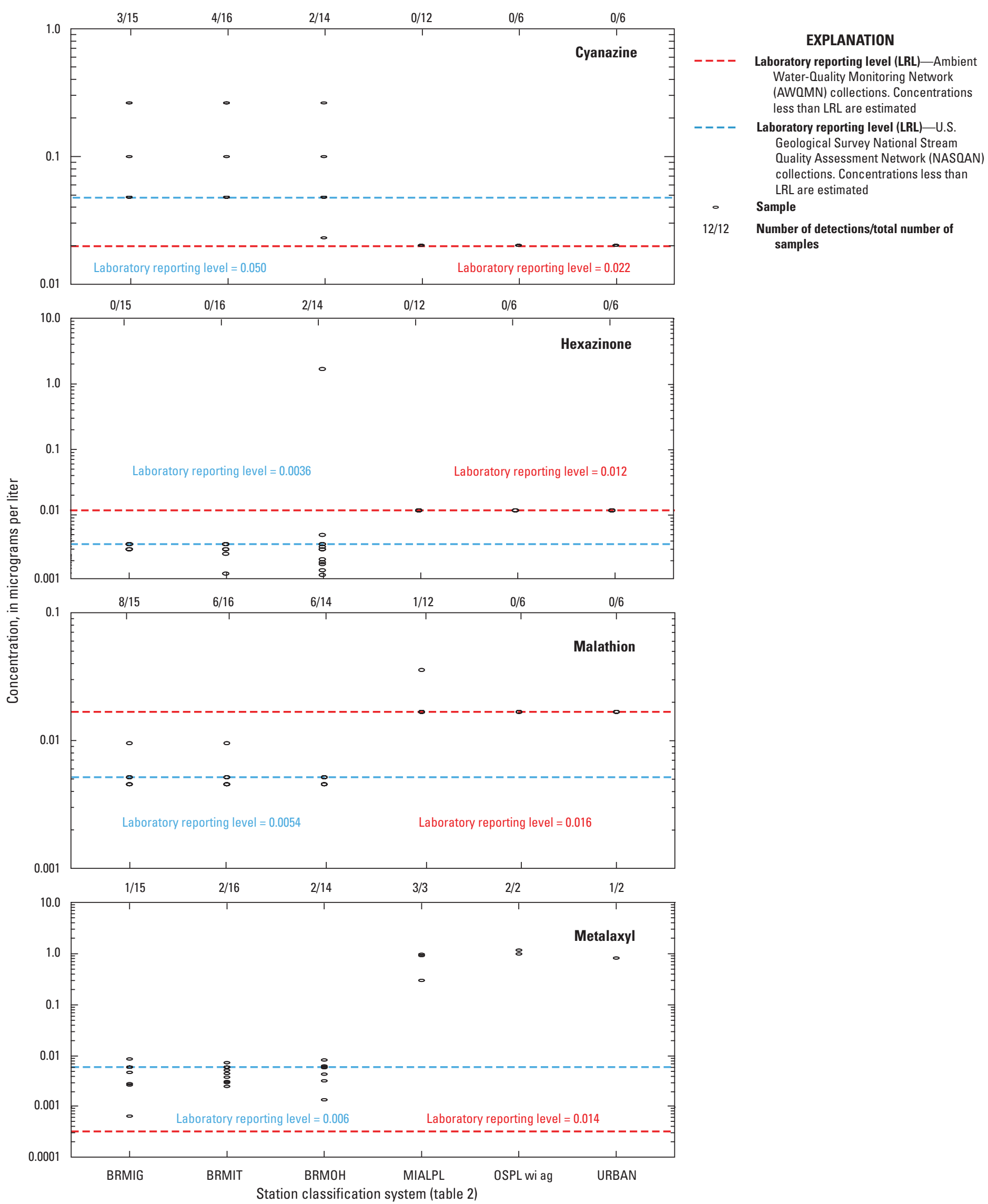

Figure 9. Detection of select pesticides from selected stations, water year 2016. - Continued 


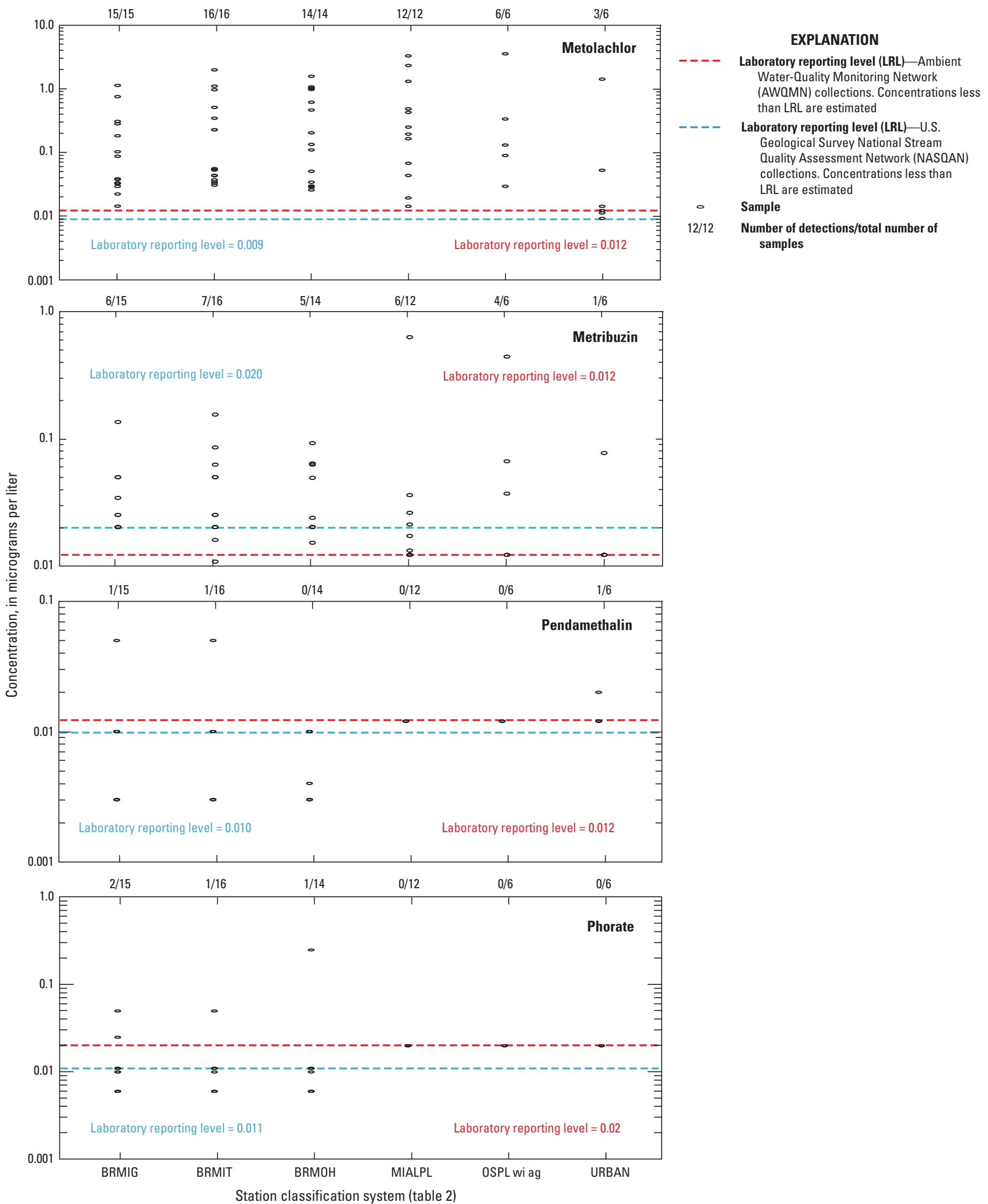

Figure 9. Detection of select pesticides from selected stations, water year 2016. - Continued 


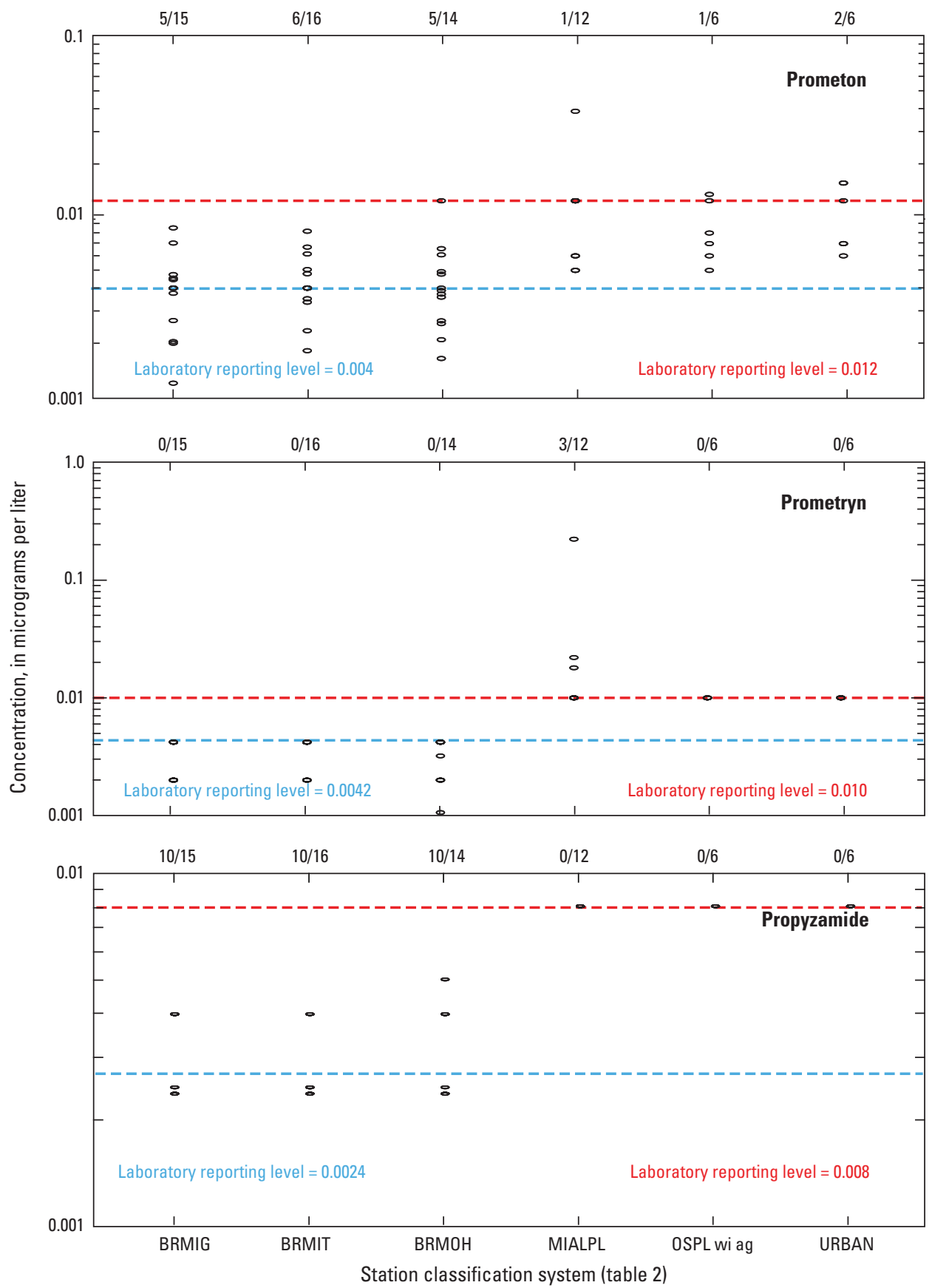

EXPLANATION

\footnotetext{
- - - - Laboratory reporting level (LRL)_Ambient Water-Quality Monitoring Network (AWOMN) collections. Concentrations less than LRL are estimated

- - - - Laboratory reporting level (LRL)—U.S. Geological Survey National Stream Quality Assessment Network (NASQAN) collections. Concentrations less than LRL are estimated

- Sample

12/12 Number of detections/total number of samples
}

Figure 9. Detection of select pesticides from selected stations, water year 2016. - Continued 

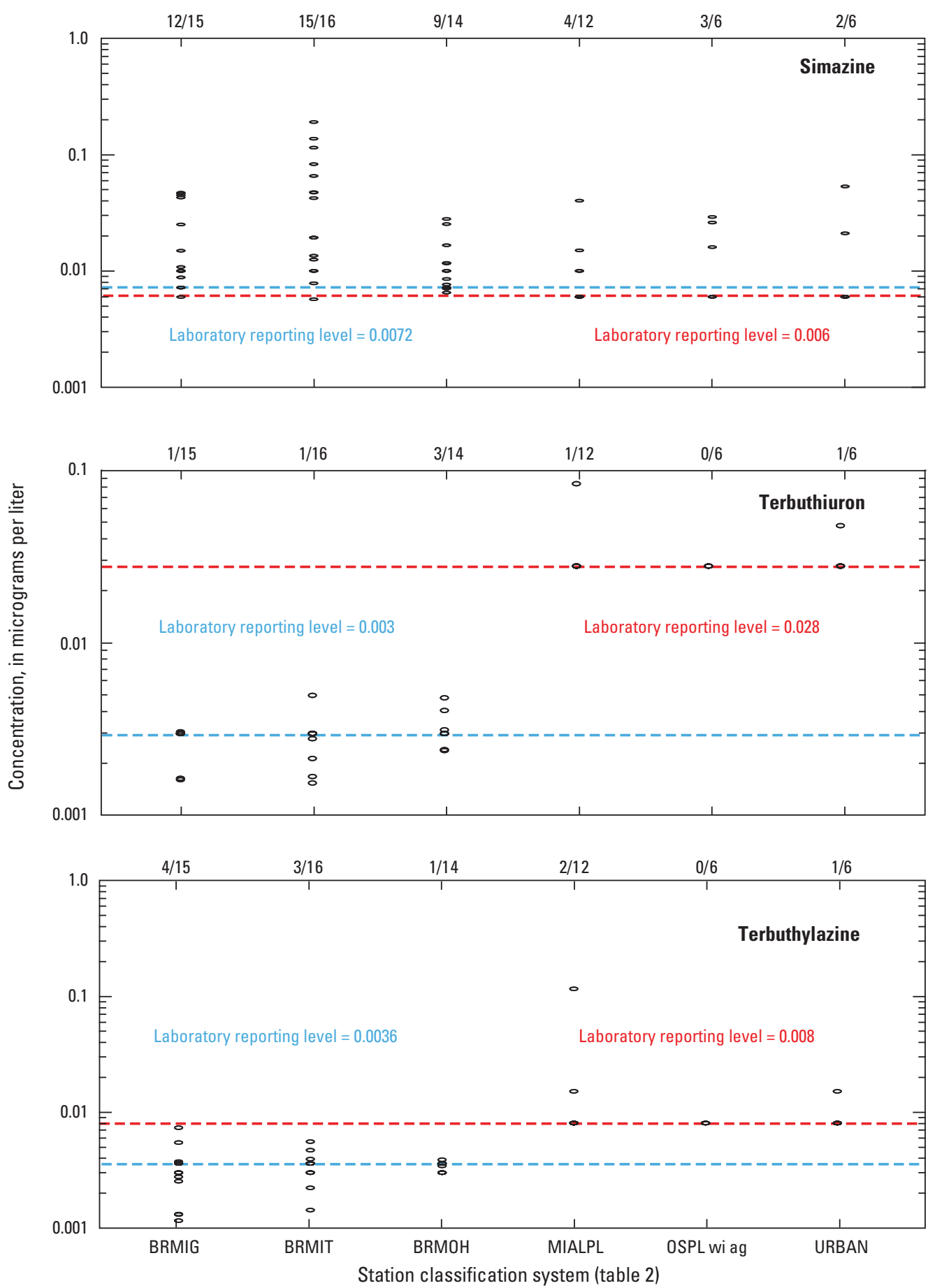

EXPLANATION

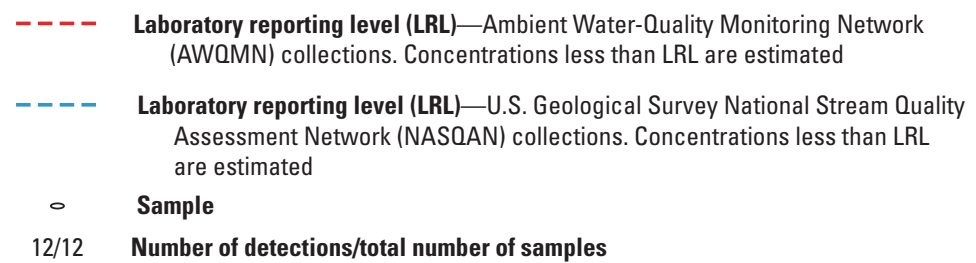

Figure 9. Detection of select pesticides from selected stations, water year 2016. - Continued 
nitrite concentrations were computed at the OSPL pr station, and the largest concentrations were computed in samples collected at the BRMIG station (fig. 7). The smallest median total phosphorus concentrations were computed at the OZPLSA (fo/ag and wi fo/ag) and SPRING stations, all of which had median values equal to the LT-MDL $(0.02 \mathrm{mg} / \mathrm{L})$, and the largest median concentration was at the $\mathrm{BRMOH}$ station (fig. 7).

\section{Distribution of Dissolved and Total Recoverable Lead and Zinc Concentrations}

Samples were collected for the analysis of dissolved and total recoverable trace elements, including lead and zinc. No dissolved or total recoverable lead and zinc samples were collected at the BRMIT and BRMOH stations. Median concentration ranges were 0.040 to 0.390 micrograms per liter $(\mu \mathrm{g} / \mathrm{L})$ of dissolved lead, 0.070 to $12.3 \mu \mathrm{g} / \mathrm{L}$ of total recoverable lead, 2.0 to $11.0 \mu \mathrm{g} / \mathrm{L}$ of dissolved zinc, and 2.0 to $30.0 \mu \mathrm{g} / \mathrm{L}$ of total recoverable zinc (fig. 8).

The smallest median concentrations of dissolved lead were computed at the LT-MDL $(0.04 \mu \mathrm{g} / \mathrm{L})$ in samples collected at BRMIG, BRMOS, MIALPL, OZPLSA (fo/ag, wi fo/ag), OZPLSP ag/fo, DTPL (ag, wi ag), OPSL wi ag, and SPRING stations; and MINING had the largest median concentration (fig. 8). Median dissolved zinc concentrations were computed at the LT-MDL $(0.04 \mu \mathrm{g} / \mathrm{L})$ for all classes and types, except OSPL pr, MINING, and URBAN; and URBAN had the largest median concentration. The smallest median concentration of total recoverable lead was computed at the SPRING stations, and the largest median concentration was computed at the MINING stations. The smallest median concentration of total recoverable zinc was the OZPLSA (fo/ ag and wi fo/ag), OZPLSP ag/fo, and SPRING stations; the largest median concentration of total recoverable zinc was computed at the BRMOS station.

\section{Concentration and Detection Frequency of Select Pesticides from Selected Stations}

Samples for the analysis of dissolved pesticides were collected at seven stations in the AWQMN, including three of the five Big River stations (BRMIG, BRMIT, and BRMOH), two stations in the MIALPL, one OSPL wi ag station, and one URBAN station. Data from 18 compounds analyzed at all stations and detected at concentrations greater than the LRL at 1 or more stations are presented graphically in this report (fig. 9). The most frequently detected pesticides were 2-chloro-4-isopropylamino-6-amino-s-triazine (88 percent detection), acetochlor ( 75 percent detection), atrazine ( 93 percent detection), metolachlor (96 percent detection), and simazine (65 percent detection). The concentrations for all pesticide compounds analyzed for all stations were less than
$1.00 \mu \mathrm{g} / \mathrm{L}$ except acetochlor (1 percent of detections), atrazine (16 percent of detections), hexazinone (1 percent of detections), metalaxyl (6 percent of detections), and metolachlor (17 percent of detections). Of the 18 pesticide compounds with concentrations larger than the LRL, 7 had the largest concentrations at the MIALPL stations (fig. 9).

\section{Summary}

The U.S. Geological Survey (USGS), in cooperation with the Missouri Department of Natural Resources (MDNR), collects surface-water quality data pertaining to water resources in Missouri each water year (October 1 through September 30). These data, stored and maintained in the USGS National Water Information System database, are collected as part of the Missouri Ambient Water-Quality Monitoring Network (AWQMN) and constitute a source of reliable, impartial, and timely information for developing an enhanced understanding of the State's water resources. In addition to the AWQMN, the USGS also collects data at two USGS National Stream Quality Assessment Network (NASQAN) stations and, in cooperation with the U.S. Army Corps of Engineers, also routinely collects suspended-sediment concentration data and various particle-size distribution data on the Missouri and Mississippi Rivers. These data assist with long-term trends in select constituents and sediment transport and navigable channel assessments along these larger rivers.

Surface-water quality data collected during water year 2016 at 71 stations (69 AWQMN and 2 NASQAN stations) are summarized in this report, among which are 4 stations with suspended-sediment data collected in cooperation with the U.S. Army Corps of Engineers. Stations were classified into groups corresponding to the physiography of the State, primary land use, or unique station types. The annual summary of select constituents provides Missouri Department of Natural Resources with current information to assess the quality of surface water within the State and ensure the objectives of the AWQMN are being met. The data collected also provide support for the design, implementation, and evaluation of preventive and remediation programs.

The analyses presented in this report include the following constituents: dissolved oxygen, specific conductance, water temperature, suspended solids, suspended sediment, Escherichia coli bacteria, fecal coliform bacteria, dissolved nitrate plus nitrite as nitrogen, total phosphorus, and dissolved and total recoverable lead and zinc. Plots of the concentrations of these constituents are presented by the different station classes. In addition, pesticide data were analyzed from seven stations from six classes. A comparison of 2016 streamflow data to long-term streamflow, a summary of hydrologic conditions in the State including peak streamflows, monthly mean streamflows, and 7-day low flows at selected stations also are presented. 


\section{References Cited}

Barr, M.N., 2010, Quality of surface water in Missouri, water year 2009: U.S. Geological Survey Open-File Report 2010-1233, 22 p., accessed October 17, 2017, at https:// pubs.usgs.gov/of/2010/1233/.

Barr, M.N., 2011, Quality of surface water in Missouri, water year 2010: U.S. Geological Survey Data Series 636, 21 p., accessed October 17, 2017, at https://pubs.usgs.gov/ds/636/.

Barr, M.N., 2013, Quality of surface water in Missouri, water year 2011: U.S. Geological Survey Data Series 734, 22 p., accessed October 17, 2017, at https://pubs.usgs.gov/ds/734/.

Barr, M.N., 2014, Quality of surface water in Missouri, water year 2012: U.S. Geological Survey Data Series 818, 24 p., accessed October 17, 2017, at https://doi.org/10.3133/ ds 818.

Barr, M.N., 2015, Quality of surface water in Missouri, water year 2014: U.S. Geological Survey Data Series 971, 22 p., accessed October 17, 2017 at https://doi.org/10.3133/ds971.

Barr, M.N., and Davis, J.V., 2010, Surface-water quality conditions and long-term trends at selected sites within the ambient water-quality monitoring network in Missouri, water years 1993-2008: U.S. Geological Survey Scientific Investigations Report 2010-5078, 42 p. [Also available at https://pubs.usgs.gov/sir/2010/5078/.]

Barr, M.N., and Heimann, D.C., 2016, Quality of surface water in Missouri, water year 2015: U.S. Geological Survey Data Series 1023, 22 p., accessed October 17, 2017, at https://doi.org/10.3133/ds1023.

Barr, M.N., and Schneider, R.E., 2014, Quality of surface water in Missouri, water year 2013: U.S. Geological Survey Data Series 886, 21 p., accessed October 17, 2017, at https://pubs.usgs.gov/ds/0886/.

Childress, C.J.O., Foreman, W.T., Connor, B.F., and Maloney, T.J., 1999, New reporting procedures based on longterm method detection levels and some considerations for interpretations of water-quality data provided by the U.S. Geological Survey National Water Quality Laboratory: U.S. Geological Survey Open-File Report 99-193, 19 p. [Also available at https://water.usgs.gov/owq/OFR_99-193/ index.html.]

Edwards, T.K., and Glysson, G.D., 1999, Field methods for measurement of fluvial sediment: U.S. Geological Survey Techniques of Water-Resources Investigations, book 3 , chap. C2, 89 p., accessed October 24, 2017, at https://pubs. usgs.gov/twri/twri3-c2/.

Fenneman, N.M., 1938, Physiography of eastern United States: New York, McGraw-Hill Book Co., Inc., 689 p.
Fishman, M.J., ed., 1993, Methods of analysis by the U.S. Geological Survey National Water Quality Laboratory-Determination of inorganic and organic constituents in water and fluvial sediments: U.S. Geological Survey Open-File Report 93-125, 217 p. [Also available at https:// pubs.er.usgs.gov/publication/ofr93125.]

Garbarino, J.R., Kanagy, L.K., and Cree, M.E., 2006, Determination of elements in natural-water, biota, sediment and soil samples using collision/reaction cell inductively coupled plasma-mass spectrometry: U.S. Geological Survey Techniques and Methods, book 5, chap. B1, 88 p. [Also available at https://pubs.usgs.gov/tm/2006/tm5b1/.]

Guy, H.P., 1969, Laboratory theory and methods for sediment analysis: U.S. Geological Survey Techniques of Water-Resources Investigations, book 5, chap. C1, accessed November 21, 2017, at https://pubs.usgs.gov/twri/twri5c1/.

Helsel, D.R., and Hirsch, R.M., 2002, Statistical methods in water resources: U.S. Geological Survey Techniques of Water-Resources Investigations, book 4, chap. A3, accessed November 13, 2017, at https://pubs.usgs.gov/twri/twri4a3/.

Missouri Department of Natural Resources, 2014a, Missouri integrated water quality report and section 303(d) list, 2014: Jefferson City, Mo., Missouri Department of Natural Resources, Water Protection Program, accessed November 21, 2017, at https://dnr.mo.gov/env/wpp/ waterquality $/ 303 \mathrm{~d} / 303 \mathrm{~d} . h \mathrm{tm}$.

Missouri Department of Natural Resources, 2014b, Water quality, chap. 7 of Rules of Department of Natural Resources-Division 20-Clean Water Commission: Jefferson City, Mo., Missouri Department of Natural Resources, Clean Water Commission, 151 p., accessed November 21, 2017, at https://s1.sos.mo.gov/cmsimages/adrules/csr/ current/10csr/10c20-7a.pdf.

Myers, D.N., Stoeckel, D.M., Bushon, R.N., Francy, D.S., and Brady, A.M.G., 2014, Fecal indicator bacteria (ver. 2.1): U.S. Geological Survey Techniques of Water-Resources Investigations, book 9, chap. A7, sec. 7.1, accessed October 26, 2017, at https://pubs.water.usgs.gov/twri9A/.

National Oceanic and Atmospheric Administration, 2018a, State of the climate-National overview-Annual 2015: National Oceanic and Atmospheric Administration, National Centers for Environmental Information, accessed October 24, 2017, at https://www.ncdc.noaa.gov/sotc/ national/201513.

National Oceanic and Atmospheric Administration, 2018b, Climate at a glance-Missouri climate summary: National Oceanic and Atmospheric Administration, National Climatic Data Center database, accessed October 24, 2017, at https:// www.ncdc.noaa.gov/cag/. 
Otero-Benitez, W., and Davis, J.V., 2009a, Quality of surface water in Missouri, water year 2007: U.S. Geological Survey Open-File Report 2009-1096, 19 p., accessed October 17, 2017, at https://pubs.usgs.gov/of/2009/1096/.

Otero-Benitez, W., and Davis, J.V., 2009b, Quality of surface water in Missouri, water year 2008: U.S. Geological Survey Open-File Report 2009-1214, 18 p., accessed October 17, 2017, at https://pubs.usgs.gov/of/2009/1214/.

Patton, C.J., and Truitt, E.P., 1992, Methods of analysis by the U.S. Geological Survey National Water Quality Laboratory-Determination of total phosphorus by a Kjeldahl digestion method and an automated colorimetric finish that includes dialysis: U.S. Geological Survey Open-File Report 92-146, 39 p. [Also available at https://pubs.er.usgs.gov/ publication/ofr92146.]

Patton, C.J., and Kryskalla, J.R., 2011, Colorimetric determination of nitrate plus nitrite in water by enzymatic reduction, automated discrete analyzer methods: U.S. Geological Survey Techniques and Methods, book 5, chap. B8, 48 p. [Also available at https://pubs.usgs.gov/tm/05b08/.]

Sandstrom, M.W., Stroppel, M.E., Foreman, W.T., and Schroeder, M.P., 2001, Methods of analysis by the U.S. Geological Survey National Water Quality LaboratoryDetermination of moderate-use pesticides and selected degradates in water by $\mathrm{C}-18$ solid-phase extraction and gas chromatography/mass spectrometry: U.S. Geological Survey Water-Resources Investigations Report 01-4098, 70 p. [Also available at https://nwql.usgs.gov/pubs/WRIR/ WRIR-01-4098.pdf.]

Sandstrom, M.W., and Wilde, F.D., 2014, Syringe-filter procedure for processing samples for analysis of organic compounds by DAI LC-MS/MS: U.S. Geological Survey Techniques of Water Resources Investigations, book 9, chap A5 sec. 2.2.B, accessed February 20, 2018, at https:// pubs.water.usgs.gov/twri9A5/.

Sandstrom, M.W., Kanagy, L.K., Anderson, C.A., and Kanagy, C.J., 2015, Determination of pesticides and pesticide degradates in filtered water by direct aqueous-injection liquid chromatography-tandem mass spectrometry: U.S. Geological Survey Techniques and Methods, book 5, chap. B11, 54 p., accessed March 19, 2018 at https://doi.org/10.3133/ tm5B11.

U.S. Census Bureau, 2016, U.S. population estimates: U.S. Census Bureau, accessed October 17, 2017, at https:// www.census.gov/.

U.S. Environmental Protection Agency, 1997, Guidelines for preparation of the comprehensive State water quality assessments (305(b) reports) and electronic updates (1997): Washington, D.C., U.S. Environmental Protection Agency, Office of Water, EPA-841-B97-002A, [variously paged], accessed March 19, 2018, at https://www.epa.gov/tmdl.
U.S. Environmental Protection Agency, 2018, Impaired waters and TMDLs: U.S. Environmental Protection Agency, Impaired Waters and TMDL Program website, accessed March 19, 2018 at https://www.epa.gov/tmdl/program-overview-impaired-waters-and-tmdls.

U.S. Geological Survey, 1964-2005, Water resources dataMissouri: U.S. Geological Survey, [variously paged].

U.S. Geological Survey, 2006a, Collection of water samples (ver. 2.0): U.S. Geological Survey Techniques of WaterResources Investigations, book 9, chap. A4, accessed February 9,2018 , at https://pubs.water.usgs.gov/twri9A4.

U.S. Geological Survey, 2006b-2010, Water resources data for the United States-Annual water-data report: U.S. Geological Survey, accessed February 9, 2018, at https://wdr.water. usgs.gov/.

U.S. Geological Survey, 2017, USGS water data for the Nation: U.S. Geological Survey National Water Information System database, accessed November 6, 2017, at https://doi. org/10.5066/F7P55KJN.

U.S. Geological Survey, variously dated, National field manual for the collection of water-quality data: U.S. Geological Survey Techniques of Water-Resources Investigations, book 9, chaps. A1-A9, accessed February 9, 2018, at https://pubs.water.usgs.gov/twri9A.

Wilde, F.D., ed., variously dated, Field measurements: U.S. Geological Survey Techniques of Water-Resources Investigations, book 9, chap. A6, accessed February 9, 2018, at https://pubs.water.usgs.gov/twri9A6/.

Wilde, F.D., Radtke, D.B., Gibs, J., and Iwatsubo, R.T., eds., 2004, with updates through 2009, Processing of water samples (ver. 2.2): U.S. Geological Survey Techniques of Water-Resources Investigations, book 9, chap. A5, accessed February 9, 2018, at https://pubs.water.usgs.gov/twri9A5/.

Zaugg, S.D., Sandstrom, M.W., Smith, S.G., and Fehlberg, K.M., 1995, Methods of analysis by the U.S. Geological Survey National Water Quality Laboratory-Determination of pesticides in water by $\mathrm{C}-18$ solid-phase extraction and capillary-column gas chromatography/mass spectrometry with selected-ion monitoring: U.S. Geological Survey Open-File Report 95-181, 49 p. [Also available at https:// pubs.usgs.gov/of/1995/0181/report.pdf.] 
For more information about this publication, contact Director, USGS Central Midwest Water Science Center 1400 Independence Road

Rolla, MO 65401

(573) 308-3667

For additional information visit https://mo.water.usgs.gov

Publishing support provided by the

Rolla Publishing Service Center 



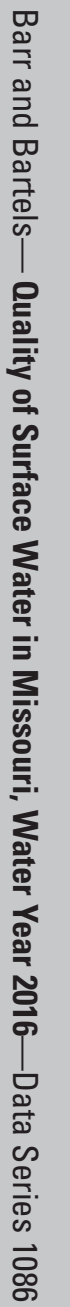

